\title{
Ventricular Arrhythmias in Ischemic Cardiomyopathy-New Avenues for Mechanism-Guided Treatment
}

\author{
Matthew Amoni ${ }^{1,2,3}$, Eef Dries ${ }^{1}$, Sebastian Ingelaere ${ }^{1,2} \mathbb{D}$, Dylan Vermoortele ${ }^{4} \mathbb{D}$, H. Llewelyn Roderick ${ }^{1}$, \\ Piet Claus ${ }^{4}$, Rik Willems ${ }^{1,2}{ }^{(D)}$ and Karin R. Sipido ${ }^{1, *}$
}

1 Experimental Cardiology, Department of Cardiovascular Sciences, KU Leuven, 3000 Leuven, Belgium; matthew.amoni@kuleuven.be (M.A.); eef.dries@kuleuven.be (E.D.); sebastian.ingelaere@kuleuven.be (S.I.); llewelyn.roderick@kuleuven.be (H.L.R.); Rik.Willems@kuleuven.be (R.W.)

2 Division of Cardiology, University Hospitals Leuven, 3000 Leuven, Belgium

3 Department of Medicine, Faculty of Health Sciences, University of Cape Town, Cape Town 7935, South Africa

4 Imaging and Cardiovascular Dynamics, Department of Cardiovascular Sciences, KU Leuven, 3000 Leuven, Belgium; dylan.vermoortele@kuleuven.be (D.V.); piet.claus@kuleuven.be (P.C.)

* Correspondence: karin.sipido@kuleuven.be or amnmat002@myuct.ac.za; Tel.: +32-16330815 or +27-64-668-5043

check for updates

Citation: Amoni, M.; Dries, E.; Ingelaere, S.; Vermoortele, D.; Roderick, H.L.; Claus, P.; Willems, R.; Sipido, K.R. Ventricular Arrhythmias in Ischemic Cardiomyopathy-New Avenues for Mechanism-Guided Treatment. Cells 2021, 10, 2629. https://doi.org/10.3390/cells10102629

Academic Editors: Ursula Ravens and Rémi Peyronnet

Received: 16 August 2021

Accepted: 23 September 2021

Published: 1 October 2021

Publisher's Note: MDPI stays neutral with regard to jurisdictional claims in published maps and institutional affiliations.

Copyright: (c) 2021 by the authors. Licensee MDPI, Basel, Switzerland. This article is an open access article distributed under the terms and conditions of the Creative Commons Attribution (CC BY) license (https:// creativecommons.org/licenses/by/ $4.0 /)$.

\begin{abstract}
Ischemic heart disease is the most common cause of lethal ventricular arrhythmias and sudden cardiac death (SCD). In patients who are at high risk after myocardial infarction, implantable cardioverter defibrillators are the most effective treatment to reduce incidence of SCD and ablation therapy can be effective for ventricular arrhythmias with identifiable culprit lesions. Yet, these approaches are not always successful and come with a considerable cost, while pharmacological management is often poor and ineffective, and occasionally proarrhythmic. Advances in mechanistic insights of arrhythmias and technological innovation have led to improved interventional approaches that are being evaluated clinically, yet pharmacological advancement has remained behind. We review the mechanistic basis for current management and provide a perspective for gaining new insights that centre on the complex tissue architecture of the arrhythmogenic infarct and border zone with surviving cardiac myocytes as the source of triggers and central players in re-entry circuits. Identification of the arrhythmia critical sites and characterisation of the molecular signature unique to these sites can open avenues for targeted therapy and reduce off-target effects that have hampered systemic pharmacotherapy. Such advances are in line with precision medicine and a patient-tailored therapy.
\end{abstract}

Keywords: arrhythmias; myocardial infarction; hypertrophy; fibrosis; cardiac remodelling; calcium; action potential

\section{The Health Challenge of Arrhythmias in Ischemic Heart Disease}

Ischemic heart disease (IHD) is the leading cardiovascular disease and largest single cause of death in the US and Europe, accounting for up to $20 \%$ of deaths [1,2]. A significant proportion of this mortality is due to sudden cardiac death (SCD), where combining acute and chronic mortality it can be estimated that approximately 50\% of deaths in IHD are due to SCD, with the other half due to heart failure and other complications $[3,4]$. SCD is attributed to lethal ventricular arrhythmias of ventricular tachycardia (VT) and fibrillation (VF), which are common complications of IHD in the acute, chronic and heart failure stage [5].

IHD has evolved dramatically in presentation over the decades. The primary pathology remains coronary artery disease due to atherosclerosis. Narrowing of coronary arteries leads to intermittent ischaemia, and complete coronary artery occlusion occurs when thrombosis superimposes on a vulnerable lesion leading to myocardial infarction (MI) [6]. Before proper treatment, immediate mortality of acute coronary occlusion and MI was over 
$30 \%$ (Figure 1A). This includes a substantial number of patients for whom SCD was the first manifestation of IHD. The immediate management of MI has evolved from the expectant conservative in the 1950s through the medical management revolution of thrombolysis in the 1980s [7], to the current status of immediate revascularisation by primary percutaneous coronary interventions. As illustrated in Figure 1A, under current guidelines, the acute mortality is now well below 5\% [8]. This reduction has led to new presentations of IHD. Survivors of MI, with substantial loss of myocardial tissue, develop ischemic cardiomyopathy (ICM) and remain at high risk of premature death because of evolution to heart failure and because of arrhythmia risk. Arrhythmic death was highest in the first 30 days after MI in the VALIANT cohort (Figure 1B), and related to left ventricular dysfunction [5]. A recent meta-analysis of 14 trials conducted in NSTEMI, reported SCD as the major cause of death and high risk of arrhythmias early but even more so after 30 days, indicating the presentation and evolution of the MI has an important role (Figure 1C) [3]. This poses new challenges. Management of arrhythmias in ICM is a major problem as risk assessment and pharmacological management are severely limited.

A

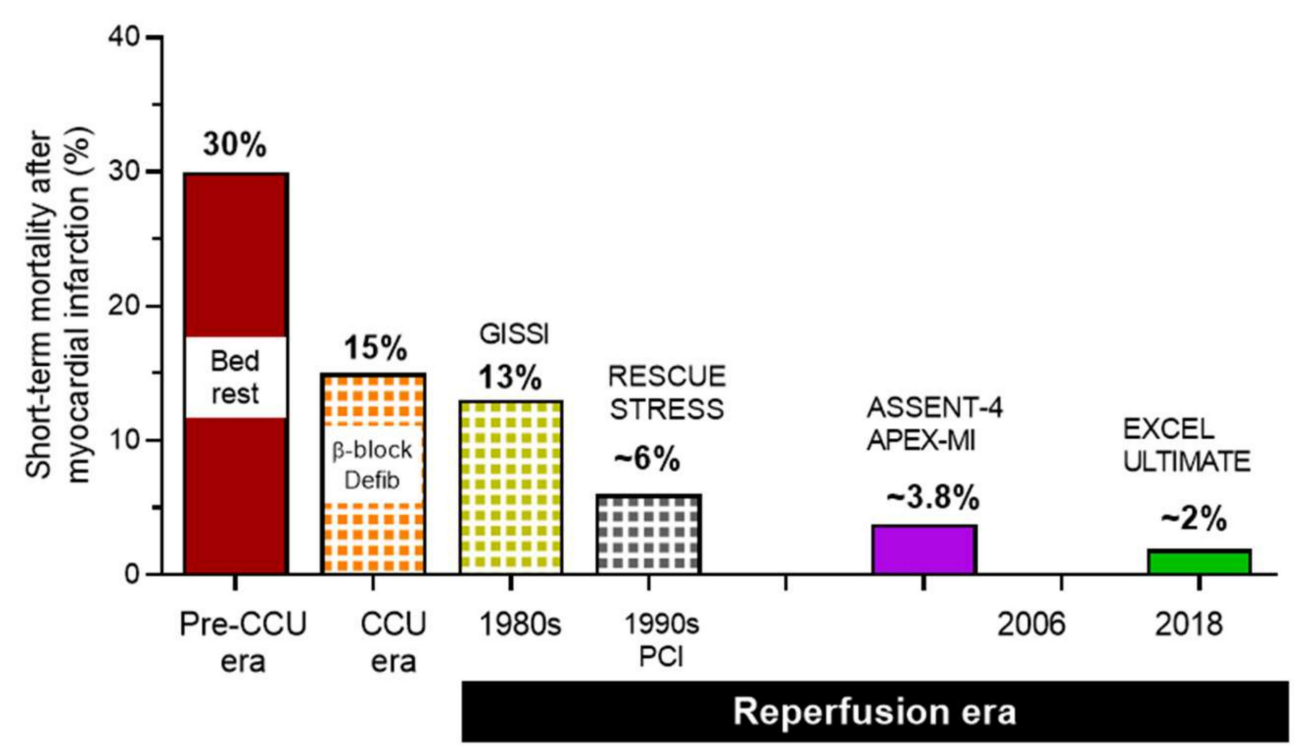

B

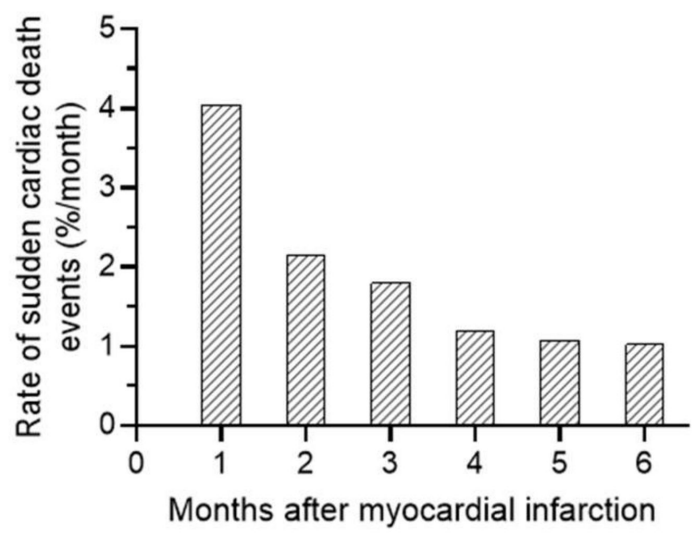

C

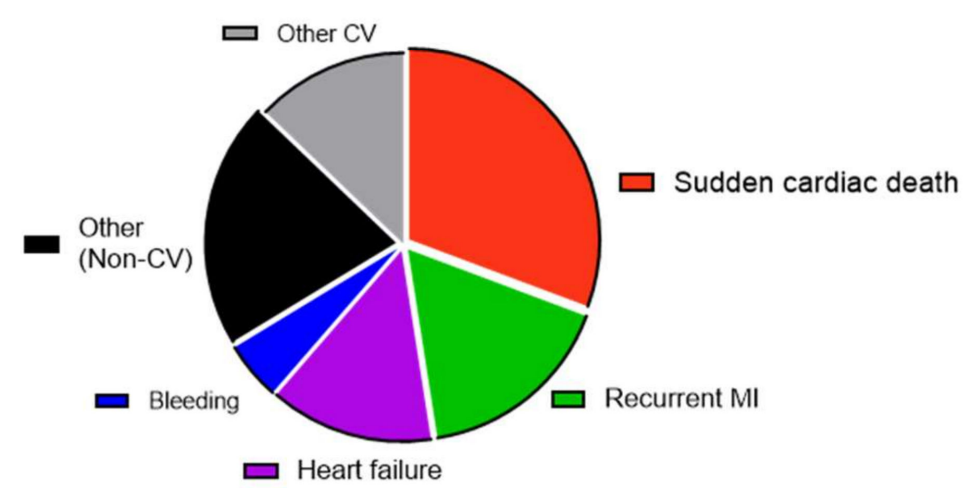

Figure 1. Sudden cardiac death and ischemic heart disease (IHD). (A) Estimated short-term mortality following myocardial infarction (Adapted from [7] and respective clinical trials). $\beta$-block- $\beta$-blocker therapy; Defib-defibrillation; CCU-coronary care unit; PCI-percutaneous coronary intervention. (B) Sudden cardiac death accounts for the largest proportion of death in IHD (Adapted from [5]). (C) Incidence rates of sudden cardiac death events (sudden cardiac death or resuscitated sudden cardiac death) in the first 6 months after myocardial infarction (Adapted from [3]). CV-cardiovascular. 
Development of novel therapeutics for ventricular arrhythmias has been stagnant, partly related to disappointments in late stage clinical trials, possibly also in part due to some complacency with available device therapy [9]. Another hurdle may also be that, despite many preclinical studies, our understanding of basic cellular pathophysiology and arrhythmia mechanisms in the infarcted heart remains incomplete. In this review, we discuss the unique nature of the presentation of arrhythmias in the presence of a healed MI and summarise what we know about electrical remodelling in the chronic phase after MI. The various factors that contribute to arrhythmia vulnerability are discussed in the context of therapeutic targeting. Finally, we present the gaps in knowledge and future research aims.

\section{Current Management: Much to Be Desired from Pharmacotherapy}

Restoring adequate circulation to the ischemic myocardium is cardinal to preserving viability and preventing further loss. Therefore, revascularisation remains central to the immediate and long-term management of IHD [10,11]. It is also important to avoiding adverse remodelling and pathological triggers associated with repetitive, demand ischaemia that can precipitate and facilitate arrhythmias and SCD [12]. Ancillary to revascularisation, cardioprotective therapies have the potential to salvage at-risk myocardium with novel therapies emerging to reduce ischemic and particularly reperfusion injury targeting multifactorial actors in acute MI [13]. Beyond revascularisation, guideline-based therapy includes beta-blockers and inhibition of the RAAS system, to reduce the extent of ventricular remodelling and evolution to heart failure. Early trials for primary pharmacological prevention of arrhythmias had disastrous outcomes with increased mortality in treated patients because of proarrhythmia [14,15]. Although beta-blockers reduce arrhythmias [16,17], they are not sufficient for prevention of SCD. Other anti-arrhythmic drugs available in IHD are amiodarone, possibly ranolazine $[9,16]$. A recent report suggested the use of agents like quinidine in select patients with refractory short coupled malignant arrhythmias [18], but no new anti-arrhythmics have been developed targeting ventricular arrhythmias in the last two decades that have shown significant promise in making their way into clinical practice.

For patients who have received the prescribed revascularisation and guideline-based medical therapy, an arrhythmia risk assessment is called for early after MI (2-40 days post-MI) if there is a clinical suspicion of high-risk (syncope, non-sustained VT, etc). Figure 2 illustrates a flowchart based on available guidelines and recommendations. Time after MI, documented VT/VF and left ventricular ejection fraction (LVEF) primarily define the risk and eventual need for an implantable cardioverter defibrillator (ICD) vs. medical optimisation and follow-up. ICD patients with intolerable symptoms or arrhythmia recurrence despite optimal medical therapy require catheter ablation or surgical neuromodulation. Of note, although the early post-MI period is recognised as highest risk (Figure 1), even after years, asymptomatic MI patients can suddenly develop lifethreatening arrhythmias, possibly related to evolving disease or comorbidities and require an ICD.

Thus, for patients at high risk, ICD is the primary treatment option and an ICD is considered the most effective therapy for the prevention of SCD in ICM [16,19]. ICDs effectively detect ventricular arrhythmias of sustained VT and VF and deliver a high-energy shock to the heart to restore normal sinus rhythm. Current guidelines for ICD implantation only have consensus regarding risk based on assessment of left ventricular ejection fraction $(\mathrm{LVEF})<35 \%$ [16]. However, it has long been understood that although the degree of left ventricle $(\mathrm{LV})$ dysfunction is the most powerful predictor of post-MI mortality, this metric is insufficient. This deficiency is further highlighted by the paradoxical evidence that the highest mortality is observed in patients with preserved, or only moderately reduced LVEF [20,21]. 


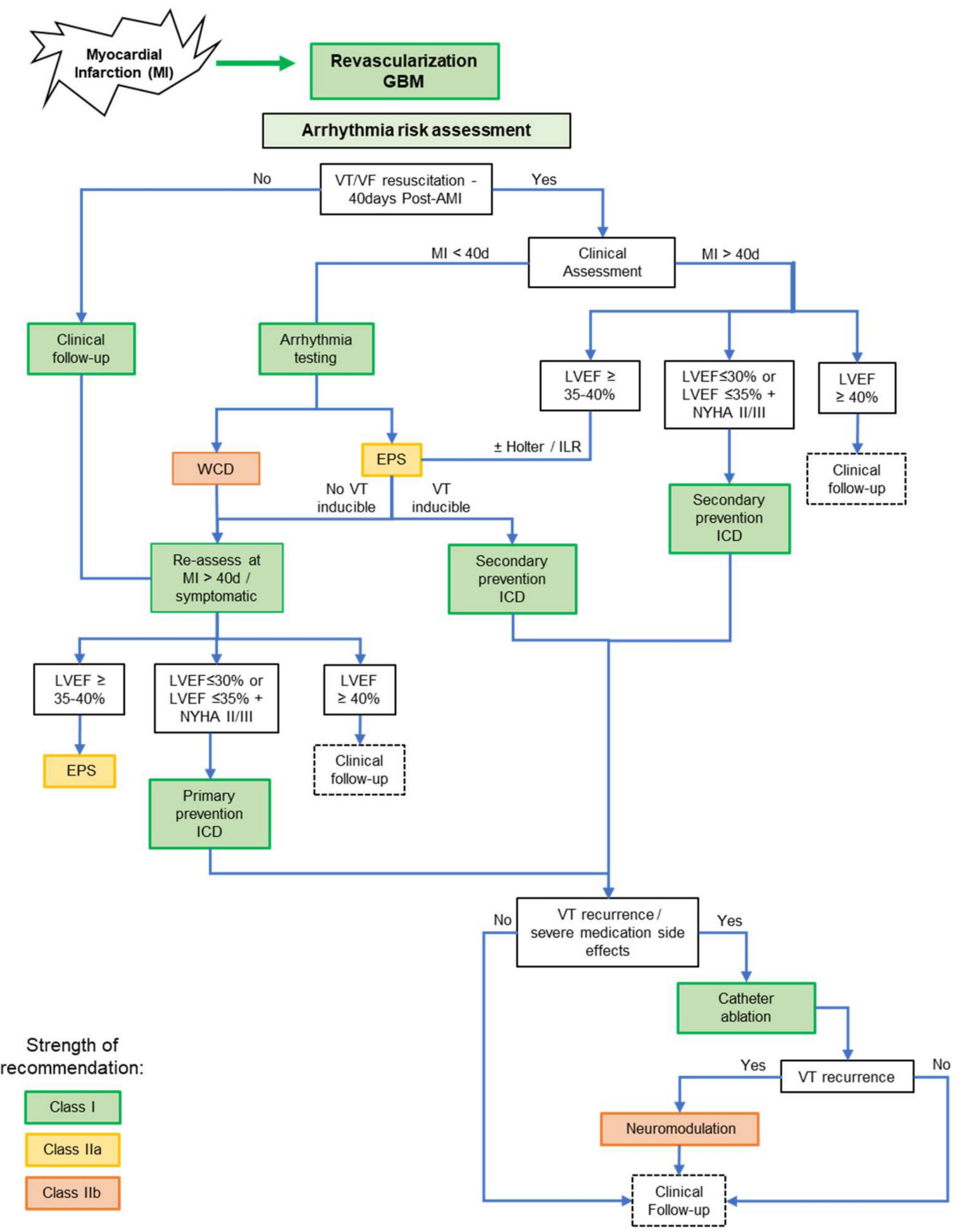

Figure 2. Risk assessment and management of ventricular arrhythmias after myocardial infarction. The flowchart was derived from [16,22,23]. Abbreviations: GBM-Guideline-based medical therapy; VT-ventricular tachycardia; VF-ventricular fibrillation; EPS-Electrophysiological study; WCD-wearable cardioverter-defibrillator; ILR-implantable loop recorder; ICD-implantable cardioverter-defibrillator. LVEF-left ventricular ejection fraction.

Classically, the invasive electrophysiology (EP) study involving arrhythmia provocation by programmed electrical stimulation via intracardiac catheters inserted transvenously is a standard for risk assessment and has its place in the diagnostic workup illustrated in Figure 2 [16,24]. However, its utility in the clinical approach to risk stratification has 
been challenged, particularly its usefulness as a screening tool [25]. Therefore, ancillary non-invasive tools and parameters have been proposed [26]. Further assessment of ischemia, a potential arrhythmia triggers is recommended by coronary angiography, stress echocardiography and nuclear scans $[16,27]$. Parameters such as infarct size, and periinfarct heterogeneity of fibrosis have been reported to predict arrhythmias, but no concrete method of assessment and evidence has found place in clinical practice [28,29]. The 24-h Holter remains one of the clinicians most valuable tool to assess an ICM patient's risk for SCD, with frequent premature ventricular complexes (PVCs), non-sustained VT and sustained VT or VF providing compelling indicators of high risk and potential benefit of ICD implantation [16,30,31]. Data obtained from ICD support the use of new markers of arrhythmic risk derived from repolarisation abnormalities [32]. A potential Holter-based parameter is beat-to-beat variability of repolarisation that shows promise of translation to ICD monitoring [33-35]. Repolarisation parameters derived from standard 12-lead electrocardiogram (ECG) analysis include QT-interval and its dispersion, T-peak to T-end and microvolt T-wave alternans, which may reflect the dynamic substrate for arrhythmias as well as depolarisation, and parameters such as QRS duration and QRS fragmentation that reflect conduction abnormalities [36,37]. These new parameters still need to be assessed comprehensively before recommendation to clinical practice [38].

A main limitation of the ICD, is that although it is effective at terminating arrhythmia, it does not prevent the occurrence of arrhythmia and may contribute to progression of disease. A high incidence of shocks to restore sinus rhythm is associated with worse outcome among ICD patients; this is possibly due to induction of electromechanical dissociation and SCD, and to repeated shocks contributing to progression of adverse remodelling [39,40]. In addition, shocks cause significant psychological distress and negatively impact patient's quality of life [41]. Thus, strategies to prevent the occurrence of arrhythmia are often used in conjunction to ICD implantation. Electrophysiology study with mapping and catheter ablation of VT is the most effective approach to prevent the occurrence of arrhythmia [42,43]. After identification of areas critical to the arrhythmia maintenance or initiation, ablation using radiofrequency energy interrupts the arrhythmia path or triggering tissue, thereby preventing arrhythmia occurrence [44]. However, ablation success is significantly lower in patients with intramural or epicardial scars and arrhythmia circuits, patients with hemodynamically unstable arrhythmias that preclude mapping or complex scars with multiple exits or polymorphic arrhythmias [45]. Patients with incessant arrhythmias or arrhythmia storm, which is refractory to ablation and medical therapy or where these are contraindicated, are considered for neuromodulation therapy $[16,46]$. In these patients, bilateral cardiac sympathetic denervation via thoracoscopic minimally invasive therapy has been shown effective with up to $60 \%$ success after three years [47], but this complex procedure is yet to be established in routine clinical practice.

Whereas ICD is a symptomatic treatment, ablation as treatment is based on the unique remodelling of the LV after MI and the consequent macroscopic mechanisms of VT. Further development of pharmacotherapy or alternative treatment will need to focus on the mechanistic basis of post-MI arrhythmias.

\section{The Unique Nature and Central Role of the Border Zone}

After MI, there are three structurally distinct regions in the LV (Figure 3A): the infarct region subjected to ischaemia, and reperfusion in most cases, where necrotic tissue is replaced by fibrosis, with scar formation preserving the wall integrity. Surrounding the infarct is a transition border zone (BZ) which was subject to relative ischaemia and collateral perfusion. Here the fraction of myocytes that survived this insult is intermixed with fibrosis. Third is the remote region that was unaffected by the ischemic insult, but which will eventually have to compensate for the loss of muscle mass.

Our understanding of the pathology and time-course of post-MI repair and remodelling has deepened through experimental studies [48]. The initial phase of MI (day 1-5) is characterised by cell death and inflammation. During this phase rapid myocyte loss occurs 
by necrosis and apoptosis, with infiltration and activation of immune cells and fibroblasts. The intermediate phase (Day 7-30) is characterised by resolution of the inflammation and replacement of myocyte loss by fibrosis leading to a myocardial infarct or scar. The chronic phase (Day 30 onwards) is the remodelling phase during which the remaining myocytes remodel to adapt to the changes due to the loss of a part of the ventricle.

A

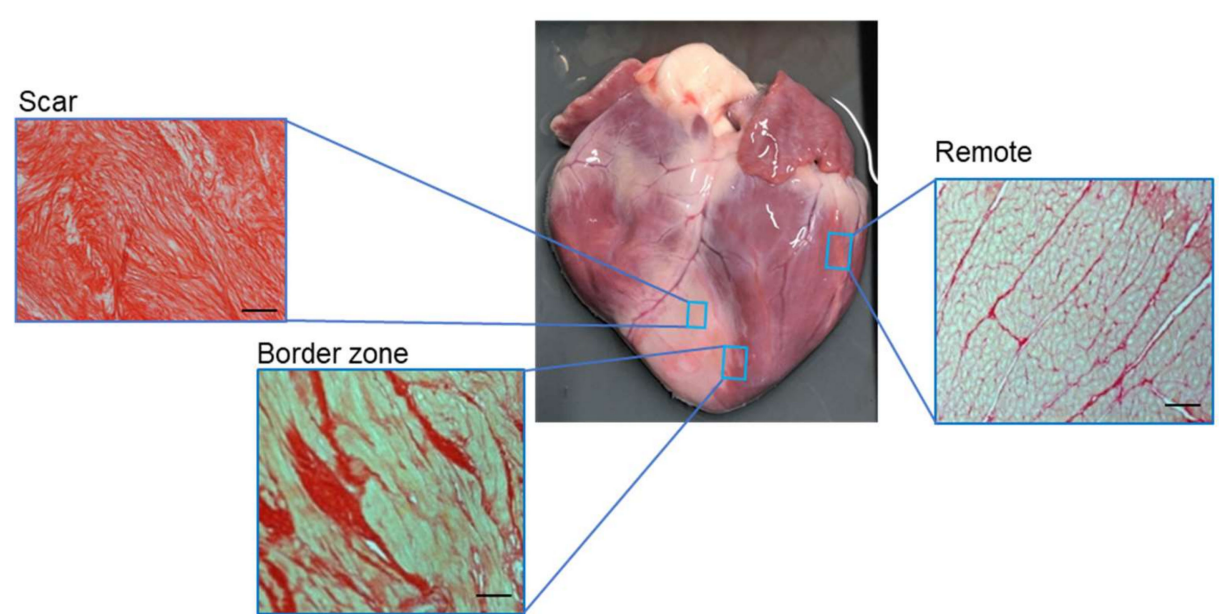

B

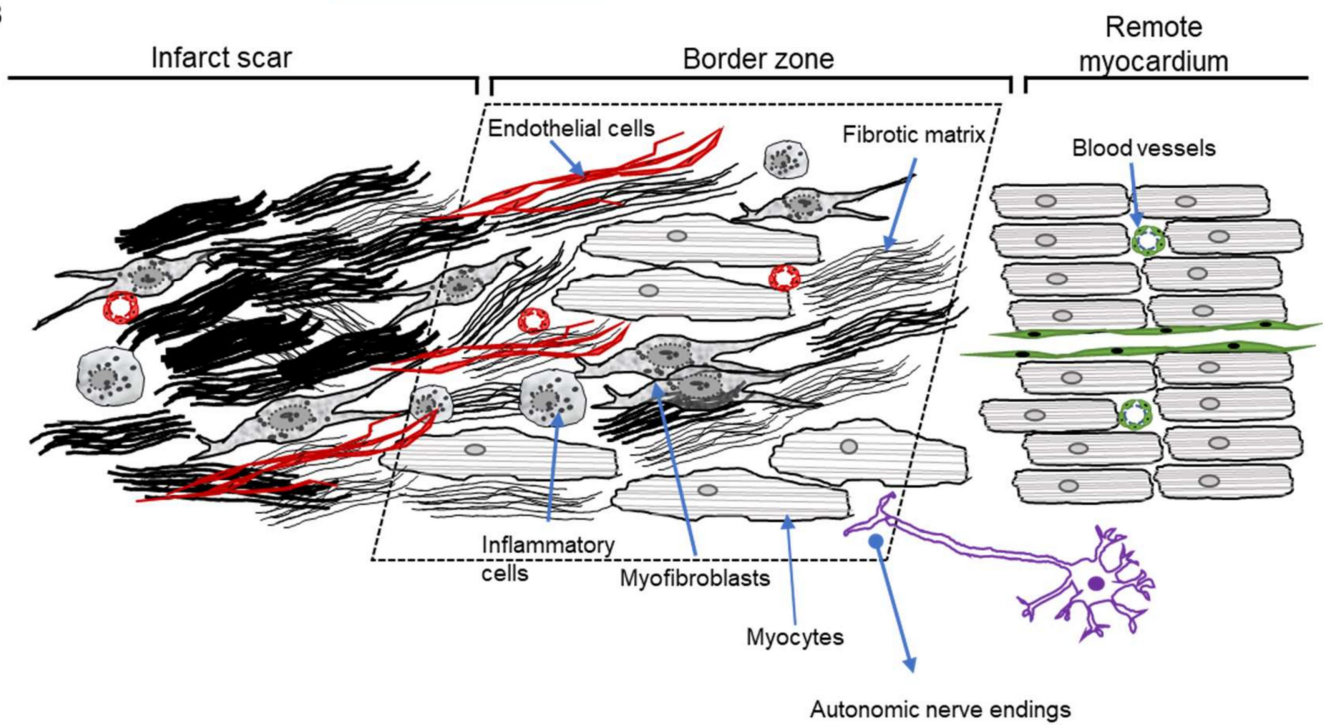

Figure 3. The unique nature of the myocardial infarction border zone. (A) Picture of a pig heart from with ischaemia/reperfusion injury-induced myocardial infarction after 1 month, illustrating the histological fibrotic structure of the scar (left insert) the mixed fibrosis and myocytes in the border zone (middle insert) and the healthy/non-infarcted remote myocardium (right insert) by Picosirius red staining (Adapted from [49]). (B) Schematic diagram illustrating the multicellular milieu of the border zone as transition between scar and myocardium without ischemic damage (remote myocardium).

The BZ formation involves a complex symphony of immune cells, including neutrophils, infiltrating monocytes, regulatory $\mathrm{T}$ cells and resident macrophages, as well as pericytes, endothelial cells and fibroblasts interacting directly and indirectly with myocytes in the BZ $[48,50,51]$.

The myocytes in the BZ undergo substantial remodelling in response to different signals. The transient ischaemia leads to activation of survival pathways such as the RISK and SAFE pathways [52,53]. The acute loss of a significant percentage of myocardium in MI results in abrupt and progressive changes of ventricular loading and local wall stress leading to abnormal strain in the surviving border zone and non-infarcted remote region, 
that contribute to remodelling and altered regional strain [54,55]. The wall stress in the scar and BZ is higher than to that of the remote myocardium primarily due to the difference in thickness [56-58], affecting fibroblast properties as well [59]. In addition, the BZ is under unique load during systole, due to the non-compliant scar tissue on one side leading to uneven mechanical forces and contraction $[55,56]$. This contributes to a BZ-specific myocyte phenotype, different from the remodelling in the remote myocardium $[49,55,57,60]$.

Another important feature of the BZ is the altered nature of the local autonomic innervation. Cardiac sympathetic nerves also suffer ischemic injury and death in the infarct region resulting in denervation [61,62]. Similar processes are observed to a lesser extent in the BZ. Here surviving neurons attempt to regenerate and sprout, leading to a heterogeneous innervation $[63,64]$. Various nerve growth factors including NGF, GAP43, and protein tyrosine phosphatase sigma (PTP) have been described to regulate neuronal re-innervation and targeting such factors can improve innervation and abate arrhythmias $[65,66]$. Following MI, the innervation of the heart undergoes remodelling in the form of denervation-re-innervation with aberrant nerve sprouting particularly in the BZ [65,67]. These processes modulate myocyte function and remodelling, influencing ion channel expression and the BZ phenotype [68]. Neurons in the non-infarcted region also undergo neuronal remodelling [69]. Moreover, extra-cardiac neuronal remodelling occurs with observed enlargement and dendritic sprouting of stellate ganglia in MI-models that further influences myocyte remodelling $[65,70,71]$.

Lastly, not only the myocardium and innervating network, but also the perfusing vasculature and microcirculation in the ischemic area are damaged with subsequent remodelling in the reperfused BZ [72,73]. The observations of a rest-stress perfusion defect mismatch in high risk patients confirms that perfusion of the BZ is dysfunctional [74,75]. In the BZ, local vascular damage, stenosis, and angiogenesis occur during infarct healing [76]. These new vessels have abnormalities of smooth muscle and organisation, leading to dysfunction particularly under stress where nitric-oxide and bradykinin-mediated vasodilatation is impaired [77-79]. This contributes to the vulnerability to ischaemia of the BZ and consequent arrhythmias.

Taken together, as illustrated in Figure 3B, the BZ microarchitecture, resulting from a complex local remodelling process, forms a unique substrate for arrhythmias in IHD as supported by in vivo studies.

\section{Origin and Maintenance of VT-Mechanistic Insights Obtained In Vivo \\ 4.1. The Conceptual Framework}

Clinical and experimental mapping and ablation studies have greatly advanced our understanding of the in vivo arrhythmogenesis in ICM. The current mechanistic framework is that underlying and pre-existing vulnerability is created through structural and functional abnormalities. In the post-MI heart, this is classically due to the scar formation and LV remodelling with creation of the unique BZ. On this substrate, initiating events, e.g., adrenergic activation, ischaemia, mechanical loading and electrolyte abnormalities, create the trigger for arrhythmias, typically a PVC (Figure 4A). Progression to VT and maintenance are mostly the result of the substrate properties.

\subsection{Triggers and Arrhythmia Initiation}

Monitoring studies have highlighted that the majority of arrhythmias in ICM are initiated by a triggering-PVC $[80,81]$. Such PVCs can be due to automaticity, triggered activity or micro-reentry.

Automaticity is implicated particularly in acute ischaemia where injury current flows between ischemic depolarised tissue and unaffected myocardium [82]. This could depolarise injured Purkinje fibres, which develop enhanced firing and trigger PVCs [83,84].

Triggered activity from afterdepolarisations is another important mechanism of PVCs and often the consequence of increased adrenergic drive, which increases intracellular calcium $[85,86]$. Clinical observations that frequent PVCs can be reproduced during an 
EP study by infusion of isoproterenol and by high rate pacing support the link between cellular events and PVCs [42,86]. Delayed afterdepolarisations (DAD) occur during phase 4 or resting membrane potential due to spontaneous calcium release leading to calcium extrusion via sodium-calcium exchanger. The resulting transient inward current induces membrane depolarisation. If these depolarisations are large enough to reach threshold for activation of $\mathrm{Na}^{+}$channels, an action potential (AP) is triggered, resulting in a PVC. Afterdepolarisations have been documented in Purkinje fibres and myocytes in ischaemia and at different stages after MI [86,87]. Myocytes within the BZ are particularly prone to DADs under adrenergic drive $[88,89]$, and during in vivo studies in the pig with MI, we recently could demonstrate co-localisation of DADs and PVC sites within the BZ (Figure 4B).

A

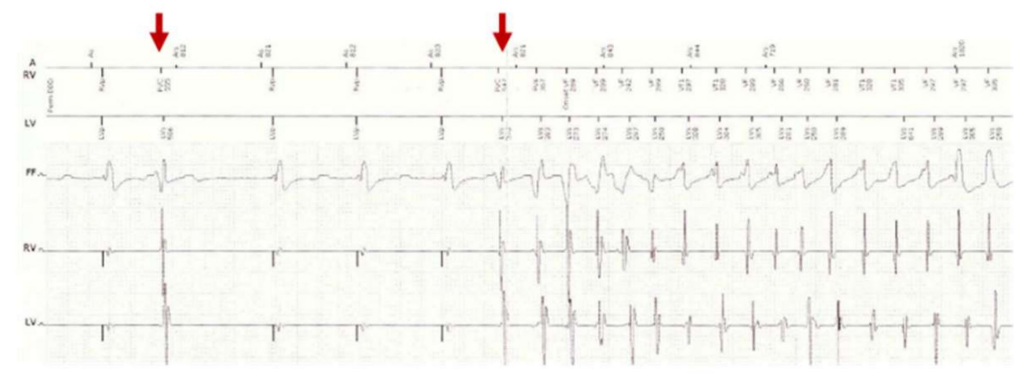

B
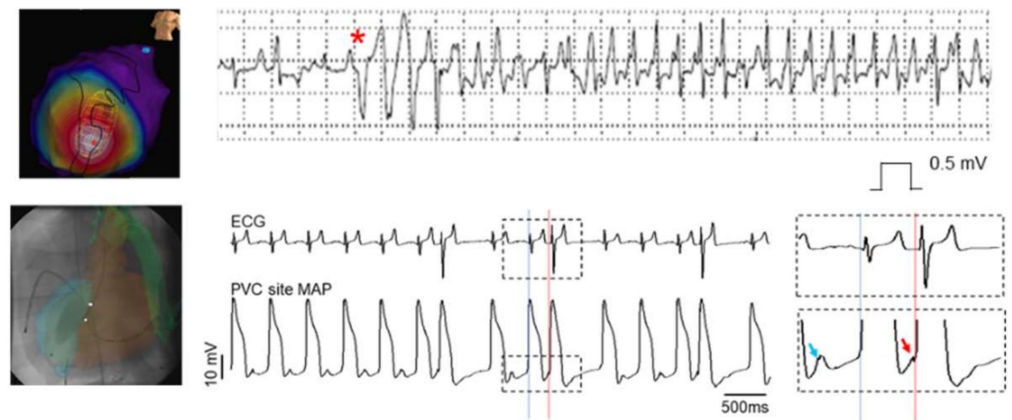

C
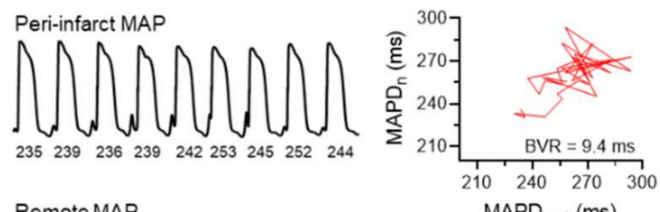

D
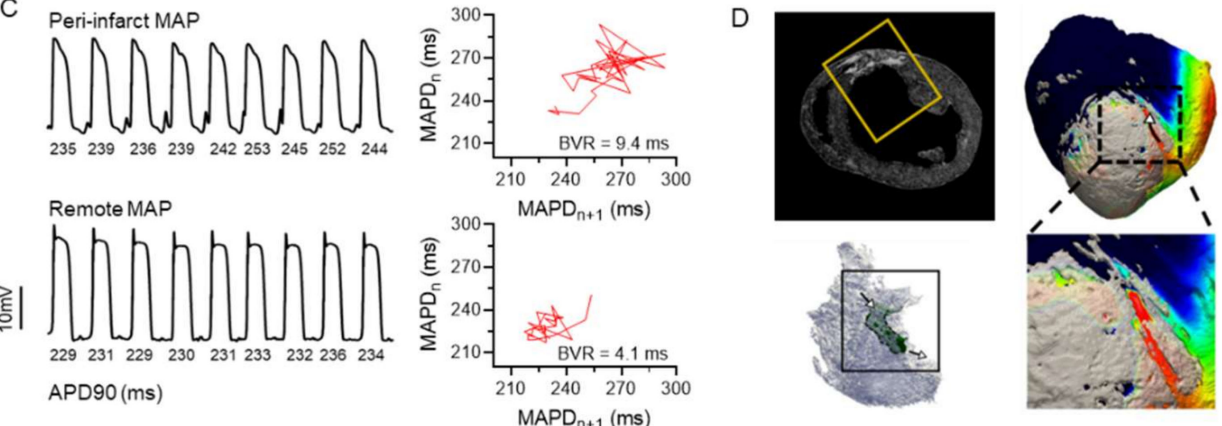

Figure 4. Arrhythmia mechanisms in vivo. (A) Example of ventricular arrhythmia initiation by a premature ventricular complex (PVC) from ICD recording of a patient. (B) Top: Initiation of ventricular tachycardia by a PVC during increased adrenergic drive from a loop recorder of an awake, freely-moving pig with ICM (top) and mapping of PVCs provoked by adrenergic stimulation in an anesthetised animal. Bottom: probing the site of PVCs utilizing monophasic action potential (MAP) catheters (right) revealed that the dominant mechanism is delayed after depolarisation-triggered activity (Adapted from [49]). (C) MAP recording illustrating beat-to-beat variability of repolarisation, a functional substrate, is increased in the border zone during sympathetic stimulation (Adapted from [89]]). (D) Illustration of the fixed scar substrate: left, example of high-definition ex vivo cardiac magnetic resonance imaging highlighting the infarct (top) used to reconstruct the infarct in 3D (bottom); right reentrant mechanism of tachycardia utilizing channel of surviving myocytes in the BZ (Adapted from [90]). 
Another possibility is micro-reentry, e.g., within the BZ. This has not been demonstrated experimentally in ICM, but it is postulated to occur where fibrosis intersperses myocytes with variable action potential duration (APD). This would allow conduction block and re-activation in a small area $<5 \mathrm{~mm}$ creating a PVC [91,92]. In this scenario, early afterdepolarisations (EADs) associated with AP prolongation, as well as dispersion of repolarisation, in space and time, are important contributing factors.

Finally, mechano-electrical feedback in vivo, e.g., during sudden increase of afterload can be part of the initiating event or PVC [93]. At cellular level, acute stretch produces membrane depolarisations that affect the AP and membrane repolarisation or resting phase interrupting it with afterdepolarisations that can trigger APs and PVCs via calcium-mediated modulation of ion channel and ryanodine receptor function [94,95]. Classical in vivo studies utilizing monophasic action potential (MAP) recordings in human surgery and altering loading conditions by transient aortic constriction demonstrated the effects of mechanical feedback on the AP and the generation of afterdepolarisations that triggered PVCs [96].

\subsection{Arrhythmia Substrates for Progression and Sustenance/Maintenance}

The BZ has a central role for arrhythmia sustenance. The structural obstacles are classically understood to induce conduction slowing as electrical activation needs to zigzag through the BZ maze around the scar, thereby allowing re-entry circuits to form [97]. In addition, it is increasingly recognised that functional abnormalities facilitate and are often essential to the re-entry circuit. Myocyte electrophysiology in the BZ is considered critical to the functional unidirectional block in the re-entry circuit $[98,99]$. Specifically, depolarisation and repolarisation differences contribute to the conduction block and allow re-activation of refractory regions allowing a re-entry loop $[98,99]$. In early experiments on post-MI VT mechanisms, El-Sherif and collaborators demonstrated by in vivo mapping the importance of the functional substrate and specifically dispersion of refractoriness, as well as the underlying myocyte-driven changes in ionic currents and APD $[100,101]$. In our recent work, we also recorded time-dependent variation in repolarisation in the BZ that likewise would facilitate re-entry (Figure 4C). Mechano-electrical coupling and regional differences in wall stress mechanics may also impact on the functional substrate and sustenance of arrhythmias. Orini et al. demonstrated using a multielectrode myocardial sock the induction of spatial inhomogeneity of repolarisation due to alterations in loading conditions that may contribute to the arrhythmia substrate and in a case report elegantly mapped the transition to arrhythmia during ischaemia in an ICM patient [102,103]. The understanding of impact of mechano-electrical feedback on electrical and mechanical activity has also been advanced greatly by the studies of mechanical dyssynchrony. Here mechanical inhomogeneity linked to ECG parameters of abnormal repolarisation is greater in ICM patients with documented arrhythmias and improves SCD prediction [104].

Recent advanced imaging combined with computational studies in experimental MI large-animal models has allowed description of the heterogeneous fibrosis and myofibre disorganisation that is characteristic of reentry circuit areas $[105,106]$. This data has led to novel clinical ablation strategies based on detailed imaging analysis to predict arrhythmia ablation sites with initial reassuring success (Figure 4D) [90]. The prescribed approach to ablation of post-MI VT typically depends upon the induction of stable arrhythmia pacing manoeuvres, like pace-mapping and entrainment, to determine the ablation target $[42,44]$. The advances in detailed 3D electro-anatomical mapping have had a profound influence on the approach for VT ablation $[107,108]$. A first improvement is the possibility to tackle critical features of the substrate identified with mapping during sinus rhythm, like isthmus or channels in the border zone of the infarct, determined by heterogeneous scar and late or isolated potentials or fragmented signals [109]. Another approach is homogenisation of the substrate, independent of critical features. By ablation of the entire BZ with relatively preserved voltages on mapping $(0.5-1.5 \mathrm{mV})$, the culprit region is rendered electrically inert and almost all potentials rendered $<0.5 \mathrm{mV}[44,110]$. Finally, in some cases of hemo- 
dynamically unstable VT or VF storm, the triggering PVCs are located and targeted for ablation [111,112]. Of these strategies, critical substrate targeting has substantially benefited from incorporation of advanced imaging into the procedure, making future changes in standard clinical practice likely. Pre-procedural magnetic resonance imaging visualises the location and extent of the infarct and fibrosis, feeding into computational modelling to create a substrate map on which critical vulnerable sites can be identified. This information is then used to personalise the ablation strategy $[96,113,114]$. Novel strategies including stereotactic non-invasive ablation, rely on preprocedural imagining for procedural planning and execution [115]. Initial success and encouraging results of accurate critical isthmus prediction from MRI reconstructions promises much to be expected from these strategies.

Despite these mechanistic insights in the role of post-MI substrate and triggers gained from in vivo studies, effective and safe anti-arrhythmic pharmacological therapy is lacking. A possible hindrance to pharmacology has been neglect of the heterogeneity of remodelling in the LV. Also, the multicellular environment of the BZ affects local myocyte remodelling and in vivo electrical function, factors that also need to be taken into account when designing molecular therapy.

\section{Cellular Remodelling in the BZ Underlying In Vivo Arrhythmogenesis \\ 5.1. Animal Models for Post-MI Remodelling}

When considering the time-dependent remodelling in vivo, the confounders of therapy and concomitant disease, and the limited access to human tissue, it is clear that animal models remain a cornerstone for the study of post-MI changes in cardiac myocyte properties. Myocyte remodelling after MI has been studied for decades, leading to progressive insights, but also confounding the field and potential translation because of the wide variety of models that have been used [116]. Variety has been in species, type of intervention to create MI and timing of the observations at myocyte level and the lack of large data sets that are inherent to patch clamp studies. Studies of the 1980s and 90s mostly used rats in a surgical coronary ligation model, whereas the dog was the typical large-animal model for MI, created during surgery. Rat studies allowed more time points to be investigated and ligation typically induces large infarcts with extensive remodelling, eventually leading to heart failure. Nowadays, creation of MI in rats and mice after ligation, is often used as a model for heart failure. An important limitation of these small-animal models for the study of BZ and remote regions, is the difficulty of regional sampling for functional single myocyte studies and consequently, mostly data come from an aggregate of cells isolated from surviving myocardium. Some of the early data on cell morphology, nevertheless already indicated the presence of regional differences in hypertrophy between near-MI and remote regions $[117,118]$ as also recently seen for the loss of T-tubules in the rat model [57]. The dog model allowed more precise regional sampling but typically had a short observation window, linked on the one hand to logistics and on the other hand to the limitation of the extensive collaterals and smaller infarcts. For these and other reasons, since the 2000s, the pig is becoming a leading animal model [119]. Pig cardiac anatomy and physiology is closer to humans, and infarcts can be created through ischaemia-reperfusion without surgery $[116,119]$. As well, surgical, and non-surgical, interventions have been developed to study chronic coronary stenosis and hibernation [120,121]. The breeding of transgenic animals with human histocompatibility genes for xenotransplantation [122,123] further increases interest in this animal model, which can be studied in vivo using clinical tools for EP studies, imaging, etc. Limitations are the logistics of handling adult pigs during long-term experiments. Logistically, sheep are easier to handle but like the dog, have coronary circulatory differences compared to man, and typically more than one coronary branch needs to be occluded to obtain large infarcts. The rabbit has been an intermediate size animal model, in terms of advantages and limitations [124,125].

In the dog and pig, different modes of MI induction have been used. In the dog, rich collateral circulation requires more extensive interventions to reduce blood flow and typically requires surgery to occlude or reduce flow in multiple coronary branches. In the 
pig, collaterals are sparser and a temporary single-vessel occlusion suffices to induce infarction. Permanent occlusive or stenosis methods to induce MI including ligation, embolisation and flow-limitation, in contrast to occlusion-reperfusion techniques such as balloon-occlusion create different phenotypes of MI. The former is likely more relevant to the pre-reperfusion/PCI era where coronary lesions remained in the chronic phase. In the current era of primary revascularisation, the ischaemia-reperfusion (I/R) models are likely more representative of the clinical phenotype, though the absence of pre-existing coronary and cardiac pathology remains a major distinction. Key differences are likely to be in the infarct and BZ, which are the principle source of arrhythmias and underlying SCD in ICM. In permanent occlusion models, the lack of blood-flow to the infarct and limited flow to the BZ limits infiltration and myocyte recovery. As such, larger infarcts are more observed in permanent occlusion compared to reperfusion [126]. Post-MI time-course in small-animal models, pre-clinical large-animal models and human MI are different as well [127]. In particular small-animal models exhibit a more rapid time-course and different qualitative features of cellular infiltration and signalling involved in infarct healing than large-animal models and human MI. Recent work suggests that the fibroblasts differentiation and invasion of the scar and BZ exhibit a unique phenotype and temporal profile as well [128,129].

In the last 20 years, mice have taken centre stage as animal model, mostly due to the power of genetic manipulation [126]. MI has mostly been induced by coronary artery ligation and mice are able to survive large infarcts of up to $40 \%$ of the LV. However, this often quickly progresses to heart failure and thus the ligation model is more suitable to study HF than early post-MI remodelling without overt HF [130]. More recently, I/R methods were introduced that are more relevant to study post-MI remodelling. However, the small size of the mouse heart makes it difficult to isolate sub-regions.

Finally, in the choice of animal models to study arrhythmic mechanisms post-MI, the electrophysiology of the myocytes is also important as species differences in ion currents shape the AP morphology with implications on repolarisation and the functional substrate for arrhythmias [131]. For small-animal models, there is a large disparity with the human $\mathrm{AP}$, though this is less of a limitation for the rabbit compared to rat and mouse [132]. The dog, sheep and pig have an AP morphology and rate response that is close to human, but none has the exact same make-up in ion channels [133].

\subsection{Myocyte Electrical Remodelling in the BZ-Role in Re-Entry and Triggered Activity}

The work done in the early years after implementation of single cell isolation, patch clamp and calcium homeostasis recordings, has informed widely about ionic channel remodelling after MI. The many studies in rats, dogs and rabbits, are rich in detail, and summarizing them briefly here does not do them full justice. Nevertheless, it is a useful starting point before turning to the specific knowledge on the $\mathrm{BZ}$, and more detail can be found in some excellent dedicated reviews $[87,134,135]$. An overarching feature of post-MI myocytes isolated from surviving myocardium, is prolongation of the AP with or without instability of the resting membrane potential. Underlying changes in ion currents responsible for AP prolongation are reduction of repolarizing early transient outward and delayed $\mathrm{K}^{+}$currents. In cells isolated from remote regions several weeks after MI, these changes are reminiscent and probably overlap with the HF phenotype also seen in humans [136]. $\mathrm{Ca}^{2+}$ current is mostly reported to be reduced, but altered $\mathrm{Na}^{+} / \mathrm{Ca}^{+}$exchange current can also contribute to long APs [137]. Gap junctional loss and re-organisation is another important feature of post-MI remodelling [138].

Early evidence showing region-specific and unique remodelling of cells from the BZ came from the work of Myerburg and colleagues. Using transmembrane recordings, they demonstrated that BZ myocytes had abnormal resting membrane potential (RMP), slower phase 1 (depolarisation) and either shorter or longer APD depending on the site as well as abnormal repolarisation and refractoriness [139]. Boyden and collaborators studied the early and intermediate-to-late remodelling in the dog post-MI model and also reported 
regional differences. Regional AP changes had a temporal pattern: in the early or acute phase (24-48 h post-MI), AP prolongation was observed consistent with reduced inward and outward K-currents [134,140]. In the sub-acute phase (5-14 days post-MI), cells studied in this intermediate phase progressively shortened AP and decreased activation velocity (measured by the maximal activation velocity of the AP upstroke, Vmax) due to a decrease in $\mathrm{I}_{\mathrm{Na}}$ current and altered kinetics; however, $\mathrm{I}_{\mathrm{K} 1}$ appeared to be reduced in these cells. In the chronic phase described as 2-months post-MI, the AP profiles and resting potential return to normal durations comparable to control cells [141]. The cellular AP profile of the chronic or stable infarct phase after one month are likely the most relevant to arrhythmias in ICM outside of the acute myocardial injury phase. At this stage, myocytes and Purkinje cells that survive in the infarct and border zone especially with timely reperfusion, may have a special role, as also indicated by clinical recordings [83,142]. Extensive work by Boyden and collaborators also demonstrated that remodelling in Purkinje cells in the chronic phase is on the one hand particular, e.g., with regard to calcium handling (see below), but also shares features with myocytes with reduced outward potassium currents and calcium current $[134,143]$.

In addition to these focused BZ studies, a number of early reports indicated that remodelling post-MI is heterogeneous with increased dispersion of repolarisation [144-146], and more recently, transmural dispersion [147]. However, few studies have directly compared cellular remodelling in the infarct/BZ region to other regions.

Table 1 gives an overview of papers that have made a direct comparison of electrical remodelling in cells isolated from more than one region in the same heart. The table is organised from top to bottom according to the time point studied after MI induction. Except for our recent paper using an I/R model, all of the studies used a permanent stenosis/occlusion. Although different in detail, they share a commonality of a BZ specific remodelling where AP is not necessarily longer, but unstable. $\mathrm{Ca}^{2+}$ current and transients are reduced but spontaneous events are present. Studying a late-stage remodelling time point of 5 months after MI, Hegyi et al. [88] presented a complete inventory of major ion channel fluxes in the BZ compared to the remote myocardium. In this model, inward $\mathrm{I}_{\mathrm{CaL}}$ is reduced in the $\mathrm{BZ}$ compared to the remote region, while $\mathrm{NCX}$ and late- $\mathrm{Na}^{+}$remained unchanged. For outward currents, $\mathrm{I}_{\mathrm{K} 1}$ is reduced in the $\mathrm{BZ}$ while $\mathrm{I}_{\mathrm{Ks}}$ and $\mathrm{I}_{\mathrm{Kr}}$ remained unchanged. These ion channel changes lead to regional differences in APD, with the BZ myocytes having significantly shorter APs than the remote.

Table 1. Regional myocyte electrical remodelling after myocardial infarction.

\begin{tabular}{|c|c|c|c|c|c|c|}
\hline Study & Species & MI Stage & Disease Model & Regions & Preparation & Observations \\
\hline $\begin{array}{l}\text { Tsujii et al., } \\
2003 \text { [148] }\end{array}$ & Rat & Acute $(2 \mathrm{~h})$ & LAD ligation & BZ (epi) vs. remote (epi) & $\begin{array}{l}\text { tissue LV (optical } \\
\text { mapping) }\end{array}$ & $\begin{array}{c}\mathrm{Ca}^{2+} \text { waves in } \mathrm{BZ} \text {, uniform } \\
\text { synchronous CaT in } \\
\text { remote. }\end{array}$ \\
\hline $\begin{array}{l}\text { Takahashi et al., } \\
2004 \text { [149] }\end{array}$ & Dog & Acute $(3-4$ h) & $\begin{array}{c}\text { Ligation side } \\
\text { branch of LCX (ex } \\
\text { vivo) }\end{array}$ & BZ (epi) vs. remote (epi) & $\begin{array}{l}\text { tissue LV (optical } \\
\text { mapping) }\end{array}$ & $\begin{array}{c}\downarrow \text { APD90, } \downarrow \mathrm{CV}, \downarrow \text { APA }, \downarrow \\
\text { diastolic potential in BZ vs. } \\
\text { remote. }\end{array}$ \\
\hline $\begin{array}{l}\text { Baba et al., } \\
2005 \text { [99] }\end{array}$ & Dog & Intermediate (5d) & LAD ligation & $\begin{array}{l}\text { central vs. outer reentry } \\
\text { path (cBZ vs. oBZ) }\end{array}$ & $\begin{array}{l}\text { single myocytes LV } \\
\text { (whole-cell } \\
\text { patch-clamp) }\end{array}$ & $\begin{array}{l}\downarrow \mathrm{I}_{\mathrm{Na}}, \downarrow \mathrm{I}_{\mathrm{CaL},} \downarrow \text { Ito in cBZ } \\
\text { and oBZ. }\end{array}$ \\
\hline $\begin{array}{l}\text { Cabo et al., } \\
2006[150]\end{array}$ & Dog & Intermediate $(5 \mathrm{~d})$ & LAD ligation & $\begin{array}{l}\text { different regions of } \\
\text { reentry path within BZ } \\
\text { (epi): central vs. outer } \\
\text { reentry path (cBZ vs. } \\
\text { oBZ) }\end{array}$ & $\begin{array}{l}\text { single myocytes } \\
\text { and tissue LV } \\
\text { (electrogram) }\end{array}$ & $\begin{array}{c}\downarrow \mathrm{CV} \text { longitudinal and } \\
\text { transverse vs. normal } \\
\text { hearts, } \downarrow \text { longitudinal CV } \\
\text { in cBZ vs. oBZ myocytes, } \\
\text { transverse CV unchanged } \\
\text { in cBZ vs. oBZ myocytes. } \\
\uparrow \mathrm{Cx} 43 \text { laterisation in cBZ } \\
\text { vs. oBZ myocytes }\end{array}$ \\
\hline $\begin{array}{l}\text { Hund T et al., } \\
2008 \text { [151] }\end{array}$ & Dog & Intermediate ( $5 \mathrm{~d})$ & $\begin{array}{l}\text { LAD ligation }(2 \mathrm{~h})+ \\
\text { reperfusion } \\
\text { In silico model }\end{array}$ & BZ (epi) vs. remote (epi) & in silico & $\begin{array}{c}\downarrow \text { CaT amplitude, } \downarrow \text { Vmax } \\
\text { in BZ vs. remote with } \\
\text { hyperactive CaMKII } \\
\uparrow \text { P-CaMKII in BZ vs. } \\
\text { remote } \\
\uparrow \text { P-CaMKII at intercalated } \\
\text { disk in BZ vs. control }\end{array}$ \\
\hline
\end{tabular}


Table 1. Cont.

\begin{tabular}{|c|c|c|c|c|c|c|}
\hline Study & Species & MI Stage & Disease Model & Regions & Preparation & Observations \\
\hline $\begin{array}{l}\text { Chou et al., } \\
2007 \text { [152] }\end{array}$ & Rabbit & Intermediate (7 d) & LCX ligation & BZ (epi) vs. remote (epi) & $\begin{array}{l}\text { tissue LV (optical } \\
\text { mapping) }\end{array}$ & $\begin{array}{l}\text { } \uparrow \text { extrasystoles in } \mathrm{BZ}, \\
\text { steeper ADP restitution in } \\
\mathrm{BZ}, \uparrow \text { pacing-induced } \mathrm{Ca}^{2+} \\
\text { alternans in } \mathrm{BZ} \text { vs. remote }\end{array}$ \\
\hline $\begin{array}{l}\text { Mills et al., } \\
2006 \text { [153] }\end{array}$ & Rat & Intermediate (7 d) & LAD ligation & BZ (epi) vs. remote (epi) & $\begin{array}{l}\text { tissue LV (optical } \\
\text { mapping) }\end{array}$ & $\begin{array}{c}\mathrm{APD} 90=\text { in BZ vs. remote, } \\
\downarrow \mathrm{CV} \text { in BZ vs. remote. }\end{array}$ \\
\hline $\begin{array}{l}\text { Pop et al., } 2012 \\
\text { [154] }\end{array}$ & Pig & Chronic (4 w) & $\begin{array}{l}\text { Balloon occlusion in } \\
\text { LAD or LCX }(90 \\
\text { min })+ \text { reperfusion }\end{array}$ & BZ (epi) vs. remote (epi) & $\begin{array}{l}\text { tissue LV (optical } \\
\text { mapping) }\end{array}$ & $\downarrow \mathrm{APD} 90$ in BZ vs. remote \\
\hline $\begin{array}{l}\text { Pinali et al., } \\
2017 \text { [155] }\end{array}$ & Pig & Chronic (4 w) & $\begin{array}{l}\text { Microbead } \\
\text { embolisation in } \\
\text { LAD side branch }\end{array}$ & $\mathrm{BZ}$ vs. remote & tissue LV sampling & $\begin{array}{c}\text { Cav1.2 }=, \text { BIN1 }=, \downarrow J P 2 \text { in } \\
\text { BZ vs. remote } \\
\downarrow \text { TT in BZ and remote vs. } \\
\text { control, } \uparrow \text { cell capacitance } \\
\text { in BZ and remote vs. } \\
\text { control. }\end{array}$ \\
\hline $\begin{array}{l}\text { Dun et al., } 2004 \\
\text { [156] }\end{array}$ & Dog & $\begin{array}{l}\text { Intermediate (14 } \\
\text { d), Chronic }(8 \mathrm{w})\end{array}$ & LAD ligation & BZ (epi) vs. remote (epi) & $\begin{array}{c}\text { single myocytes LV } \\
\text { (whole-cell } \\
\text { patch-clamp) }\end{array}$ & $\begin{array}{c}14 \mathrm{~d}: \downarrow \mathrm{I}_{\mathrm{CaL}} \text { in } \mathrm{BZ} \text { vs. } \\
\text { remote, } \uparrow \mathrm{ISO} \text { effect in } \\
\text { remote (presence of } \\
\text { regional heterogeneity in } \\
\text { adrenergic response); } \downarrow \mathrm{I}_{\text {to }} \\
\text { in } \mathrm{BZ} \text { vs. remote } \\
8 \mathrm{w}: \downarrow \mathrm{I}_{\mathrm{CaL}} \text { in } \mathrm{BZ} \text { and } \\
\text { remote, no ISO effect in BZ } \\
\text { and remote (absence of } \\
\text { regional heterogeneity in } \\
\text { adrenergic response); } \mathrm{I}_{\mathrm{to}}= \\
\text { in } \mathrm{BZ} \text { vs. remote } \\
\text { cell capacitance = in BZ vs. } \\
\text { remote }\end{array}$ \\
\hline $\begin{array}{l}\text { Dries and } \\
\text { Amoni et al., } \\
2020 \text { [89] }\end{array}$ & Pig & Chronic (6 w) & $\begin{array}{l}\text { Copper-coated stent } \\
\text { in LAD }\end{array}$ & $\begin{array}{l}\text { BZ (mid) vs. remote } \\
\text { (mid) }\end{array}$ & $\begin{array}{c}\text { single myocytes LV } \\
\text { (whole-cell } \\
\text { patch-clamp) }\end{array}$ & $\begin{array}{l}\uparrow \text { DADs and spontaneous } \\
\text { AP in BZ vs. remote, } \uparrow \\
\text { BVR in BZ vs. remote (with } \\
\text { adrenergic signalling). } \\
\text { Gene expression } \uparrow \\
\text { NPPA in BZ vs. remote. } \\
\uparrow \text { cell width, = cell length, } \\
=\text { TTs in BZ vs. remote. }\end{array}$ \\
\hline $\begin{array}{l}\text { Kim et al., } 2002 \\
\text { [157] }\end{array}$ & Sheep & Chronic (8 w) & LAD ligation & $\begin{array}{l}\text { BZ (endo) vs. remote } \\
\text { (endo) }\end{array}$ & $\begin{array}{c}\text { single myocytes LV } \\
\text { (whole-cell } \\
\text { patch-clamp) }\end{array}$ & $\begin{array}{c}\downarrow \mathrm{I}_{\mathrm{CaL}}, \downarrow \text { CaT amplitude, } \uparrow \\
\text { CaT relaxation time, } \downarrow \\
\text { contraction in BZ vs. } \\
\text { remote. } \\
\downarrow \text { SERCA in BZ vs. remote. } \\
\uparrow \text { cell length, } \uparrow \text { cell width, } \uparrow \\
\text { cell capacitance in BZ vs. } \\
\text { remote. }\end{array}$ \\
\hline $\begin{array}{l}\text { Shimkunas } \\
\text { et al., } 2013 \\
\text { [158] }\end{array}$ & Sheep & Chronic (17 w) & LCX ligation & BZ (epi) vs. remote (epi) & $\begin{array}{l}\text { tissue LV (force } \\
\text { measurements) }\end{array}$ & $\begin{array}{c}\downarrow \text { force development in BZ } \\
\text { vs. remote }\end{array}$ \\
\hline $\begin{array}{l}\text { Wong et al. } \\
1982 \text { [139] }\end{array}$ & Cat & $\begin{array}{l}\text { Chronic (2-7 } \\
\text { months) }\end{array}$ & $\begin{array}{l}\text { Ligation side } \\
\text { branches of LAD } \\
\text { and LCX }\end{array}$ & $\begin{array}{l}\text { BZ (endo) vs. remote } \\
\text { (endo) }\end{array}$ & $\begin{array}{c}\text { tissue LV } \\
\text { (microelectrode) }\end{array}$ & $\begin{array}{c}\downarrow \text { APD90, } \downarrow \text { RMP } \\
\text { (depolarised), } \downarrow \text { Vmax in } \\
\text { BZ vs. remote }\end{array}$ \\
\hline $\begin{array}{l}\text { Kimura et al. } \\
1986 \text { [159] }\end{array}$ & Cat & $\begin{array}{l}\text { Chronic (2-6 } \\
\text { months) }\end{array}$ & $\begin{array}{l}\text { Ligation side } \\
\text { branches of LAD } \\
\text { and LCX }\end{array}$ & $\begin{array}{l}\text { BZ (endo) vs. remote } \\
\text { (endo) }\end{array}$ & $\begin{array}{c}\text { tissue LV } \\
\text { (ion-sensitive } \\
\text { microelectrodes) }\end{array}$ & $\underset{\text { remote }}{\downarrow\left[\mathrm{K}^{+}\right], \uparrow\left[\mathrm{Na}^{+}\right] \text {in } \mathrm{BZ} \mathrm{vs.} .}$ \\
\hline $\begin{array}{l}\text { Pinto et al. } \\
1997[160]\end{array}$ & Cat & $\begin{array}{c}\text { Chronic }(>2 \\
\text { months) }\end{array}$ & $\begin{array}{c}\text { Ligation side } \\
\text { branches of LAD }\end{array}$ & $\begin{array}{l}\text { BZ (endo) vs. remote } \\
\text { (endo) }\end{array}$ & $\begin{array}{c}\text { single myocytes LV } \\
\text { (whole-cell } \\
\text { patch-clamp) }\end{array}$ & $\begin{array}{c}\downarrow \mathrm{I}_{\mathrm{CaL}} \text { in } \mathrm{BZ} \text { and remote vs. } \\
\text { control, } \downarrow \text { APD in BZ, } \uparrow \\
\text { ADP in remote } \\
\uparrow \text { cell capacitance in remote } \\
\text { vs. BZ/control }\end{array}$ \\
\hline $\begin{array}{l}\text { Kimura et al. } \\
1988[161]\end{array}$ & Cat & $\begin{array}{c}\text { Chronic (>2 } \\
\text { months) }\end{array}$ & $\begin{array}{l}\text { Ligation side } \\
\text { branches of LAD } \\
\text { and LCX }\end{array}$ & $\begin{array}{l}\text { BZ (endo) vs. remote } \\
\text { (endo) }\end{array}$ & $\begin{array}{c}\text { tissue LV } \\
\text { (microelectrode) }\end{array}$ & $\begin{array}{l}\mathrm{RMP}=, \mathrm{APA}=, \mathrm{APD} 90= \\
\mathrm{APD} 50=\text { in } \mathrm{BZ} \text { vs. remote }\end{array}$ \\
\hline $\begin{array}{l}\text { Weigand et al., } \\
2016 \text { [162] }\end{array}$ & Rat & Chronic (6 w) & LAD ligation & BZ (epi) vs. remote (epi) & $\begin{array}{l}\text { whole heart (in vivo } \\
\text { LV mapping) }\end{array}$ & $\begin{array}{l}\downarrow \text { MAPA, } \uparrow \text { heterogeneity } \\
\text { of repolarisation, } \downarrow \text { Vmax, } \\
\text { MAPD }=\text { in BZ vs. remote }\end{array}$ \\
\hline $\begin{array}{l}\text { Walker et al., } \\
2007[163]\end{array}$ & Rabbit & Chronic (8 w) & LCX ligation & BZ (epi) vs. remote (epi) & $\begin{array}{l}\text { tissue LV (optical } \\
\text { mapping) }\end{array}$ & $\downarrow \mathrm{CV}$ in $\mathrm{BZ}$ vs. remote \\
\hline $\begin{array}{l}\text { Dangman et al. } \\
1982[164]\end{array}$ & Human & $\begin{array}{c}\text { Chronic } \\
\text { (end-stage HF) }\end{array}$ & - & $\begin{array}{l}\text { BZ (endo) vs. remote } \\
\text { (endo) }\end{array}$ & $\begin{array}{c}\text { tissue LV } \\
\text { (microelectrode) }\end{array}$ & $\begin{array}{c}\mathrm{ADP} 50=, \mathrm{ADP} 100=, \mathrm{Vmax} \\
=, \mathrm{RMP}=, \mathrm{APA}=\text { in } \mathrm{BZ} \text { vs. } \\
\text { remote }\end{array}$ \\
\hline
\end{tabular}


Table 1. Cont.

\begin{tabular}{|c|c|c|c|c|c|c|}
\hline Study & Species & MI Stage & Disease Model & Regions & Preparation & Observations \\
\hline $\begin{array}{l}\text { Heygi et al., } \\
2018 \text { [88] }\end{array}$ & Pig & $\begin{array}{l}\text { Chronic (5 } \\
\text { months) }\end{array}$ & $\begin{array}{c}\text { Microbead } \\
\text { embolisation in } \\
\text { LAD side branch }\end{array}$ & BZ vs. remote & $\begin{array}{c}\text { single myocytes LV } \\
\text { (whole-cell } \\
\text { patch-clamp) }\end{array}$ & $\begin{array}{c}\downarrow \mathrm{APD} 95 \text { in } \mathrm{BZ}, \uparrow \mathrm{APD} 95 \text { in } \\
\text { remote, CaT } \\
\text { amplitude } / \text { relaxation }=, \\
\mathrm{I}_{\mathrm{Na}}=, \downarrow \mathrm{I}_{\mathrm{Ca}}, \downarrow \mathrm{I}_{\mathrm{K} 1}, \mathrm{I}_{\mathrm{Kr}}=, \\
\mathrm{I}_{\mathrm{NCX}}=, \mathrm{I}_{\mathrm{Ks}}=, \uparrow \mathrm{DAD} / \mathrm{AP} \\
\text { frequency in } \mathrm{BZ} \text { vs. remote } \\
\downarrow \text { cell shortening in } \\
\mathrm{BZ} / \text { remote vs. control, }= \\
\text { cell shortening in } \mathrm{BZ} \text { vs. } \\
\text { remote }\end{array}$ \\
\hline $\begin{array}{c}\text { Loennechen } \\
\text { et al., } 2002 \\
{[165]}\end{array}$ & Rat & Chronic (56 d) & LAD ligation & $\begin{array}{l}\text { Remote vs. sham, } \\
\text { Remote vs. BZ }\end{array}$ & single myocytes LV & $\begin{array}{c}\uparrow \text { diastolic and systolic } \\
{\left[\mathrm{Ca}^{2+}\right] \text { in remote MI vs. }} \\
\text { sham; = diastolic and } \\
\text { systolic }\left[\mathrm{Ca}^{2+}\right] \text { in remote vs. } \\
\text { BZ } \\
\uparrow \text { cell length, } \uparrow \text { cell width } \\
\text { in remote vs. sham; = cell } \\
\text { length, = cell width in } \\
\text { remote vs. BZ } \\
\text { cell shortening }=\text { in remote } \\
\text { vs. BZ }\end{array}$ \\
\hline $\begin{array}{c}\text { Kilic et al., } 2006 \\
\text { [166] }\end{array}$ & Sheep & Chronic (8 w) & LAD ligation & BZ vs. remote & $\begin{array}{l}\text { whole heart (in vivo } \\
\text { LV echo) }\end{array}$ & $\begin{array}{l}\downarrow \text { SERCA, } \downarrow \text { PLB in } \\
\text { peri-infarct vs. remote } \\
\text { (correlated with regional } \\
\text { strain on echo) }\end{array}$ \\
\hline $\begin{array}{l}\text { Tomek et al., } \\
2019 \text { [167] }\end{array}$ & Rat & Chronic (8 w) & $\begin{array}{l}\text { Antero-apical } \\
\text { cryo-infarction }\end{array}$ & BZ (epi) vs. remote (epi) & $\begin{array}{l}\text { tissue LV (optical } \\
\text { mapping) }\end{array}$ & $\begin{array}{c}\uparrow \text { alternans at longer cycle } \\
\text { length in BZ vs. remote at } \\
\text { baseline; } \downarrow \text { alternans at } \\
\text { longer cycle length in BZ } \\
\text { vs. remote during } \\
\text { adrenergic signalling }\end{array}$ \\
\hline
\end{tabular}

LAD—left anterior descending; LCX—-left circumflex; LV—left ventricle; epi-epicardium; BZ—-border zone; $\mathrm{CaT}_{-} \mathrm{Ca}^{2+}$ transient; APDaction potential duration; CV—conduction velocity; APA—action potential amplitude; Cx43—connexin-43; cBZ—central border zone; oBZ—outer border zone; P-CaMKII—phosphorylated $\mathrm{Ca}^{2+}$-calmodulin kinase 2; Cav—Calcium channel protein; BIN—bridging integrator; JP2—junctophilin; TT—-transvers tubule; $\mathrm{I}_{\mathrm{CaL}}$-long $\mathrm{Ca}^{2+}$ current; ISO—Isoproterenol; DAD—delayed afterdepolarisation; BVR—beat-tobeat variability of repolarisation; $\mathrm{RMP}$ - resting membrane potential; Vmax = maximum upstroke velocity of action potential; $\mathrm{I}_{\mathrm{to}}$ transient outward $\mathrm{K}^{+}$current NPPA - Natriuretic peptide A; SERCA—sarco/endoplasmic reticulum $\mathrm{Ca}^{2+}$-ATPase; $\mathrm{I}_{\mathrm{Na}}-\mathrm{Na}^{+}$current; $\mathrm{I}_{\mathrm{K} 1}$-inward rectifying $\mathrm{K}^{+}$current; $\mathrm{I}_{\mathrm{Kr}}$-rapid-delayed rectifying $\mathrm{K}^{+}$current; $\mathrm{I}_{\mathrm{NCX}} \mathrm{Na}^{+}-\mathrm{K}^{+}$exchange current; $\mathrm{I}_{\mathrm{Ks}}$-slow-delayed rectifying $\mathrm{K}^{+}$current; MAPA - monophasic action potential amplitude; MAPD = monophasic action potential duration; PLB — phospholamban.

Our own recent data come from an I/R model, studied at four weeks when the incidence of spontaneous arrhythmias is high [49]. Different from Hegyi et al., we did find not find shorter APs but found that the resting membrane potential was unstable with reduced $\mathrm{I}_{\mathrm{K} 1}$ under adrenergic stimulation, facilitating triggered APs (Figure 5A-C).

These latter findings relate to changes in calcium handling. Cells from infarcted hearts, not specifically from the $\mathrm{BZ}$, were previously reported to have decreased $\mathrm{I}_{\mathrm{CaL}}$ and increased ryanodine receptor (RyR)-responsiveness leading to frequent spontaneous calcium release events $[137,168,169]$. Also, in the pig, following a non-reperfused MI, BZ myocytes have increased spontaneous calcium release compared to remote myocytes leading to frequent DADs due to calcium extrusion via the NCX during adrenergic [89]. We recently studied the relation between cellular remodelling and in vivo events, in the I/R MI model [49]. Here we could show that myocyte-driven DAD events co-localise with the sites of origin of frequent PVCs in vivo (Figure 4B), suggesting that calcium handling abnormalities and DAD-triggered APs could be a dominant mechanism underlying PVCs originating from the $\mathrm{BZ}$ in the infarcted heart. Of note, DADs contribute to AP temporal variation and beat-to-beat variability of repolarisation (Figure 5D).

In Purkinje cells as well, Boyden et al. documented extensively the occurrence of calcium waves and their propagation, as a potential source of triggered activity from the BZ $[170,171]$ corroborated by others in Purkinje fibre preparations [84]. Purkinje cells have a latent pacemaker function and calcium-driven depolarisation contributes to this automaticity, while Purkinje cells surviving post-MI have more spontaneous activity in vitro [172]. Clinically there have been recordings of premature ventricular complex (PVC) that indicated a Purkinje fibre origin. Both Purkinje cells and cardiomyocytes can have spontaneous calcium release that triggers PVCs, but whether there is a fundamental 
difference, or a cell preference between them as a potential PVC source, awaits a head-tohead comparison. Such abnormalities could play a central role in triggering PVCs that are central to arrhythmia initiation. Moreover, a unifying hypothesis is to consider the interplay between myocyte-DADs and Purkinje depolarisations, which could interact synergistically via parasystolic modulation to result in the manifestation of PVCs [173].

A

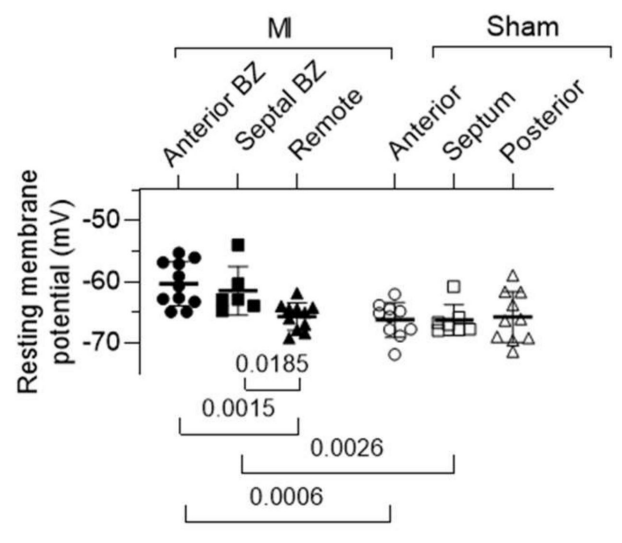

B
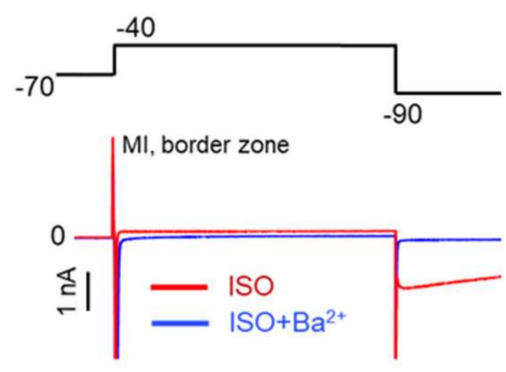
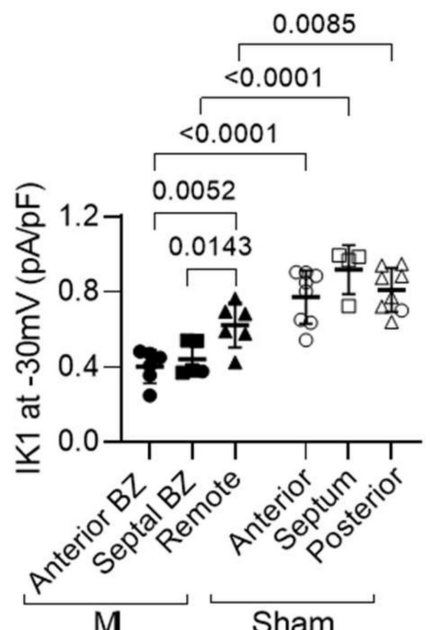

C
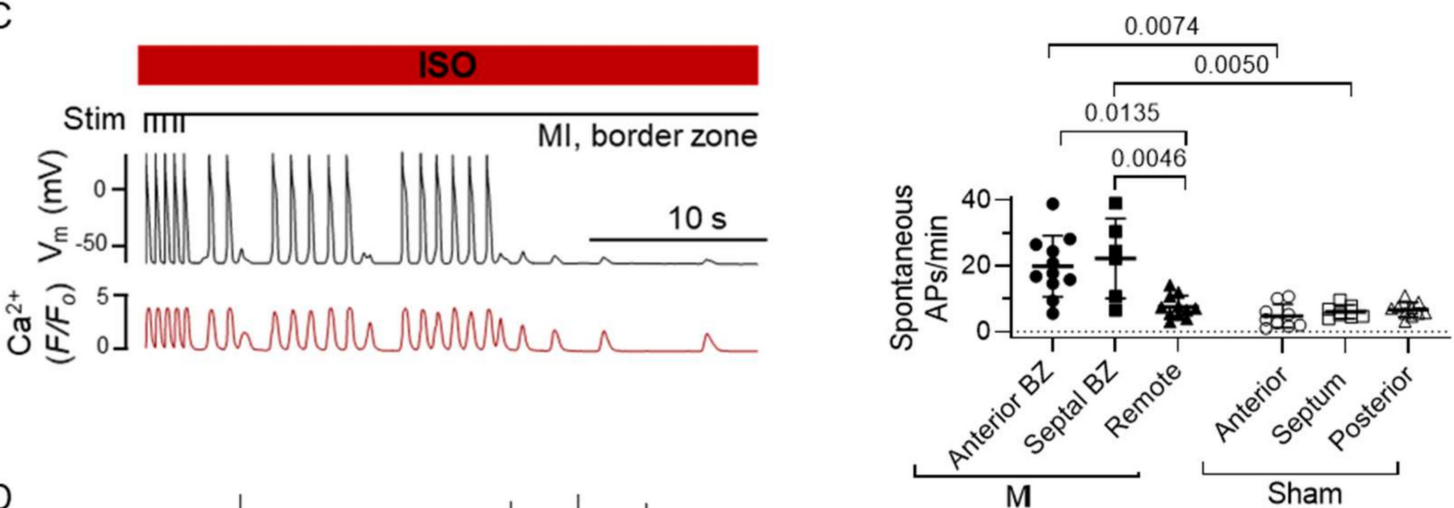

D
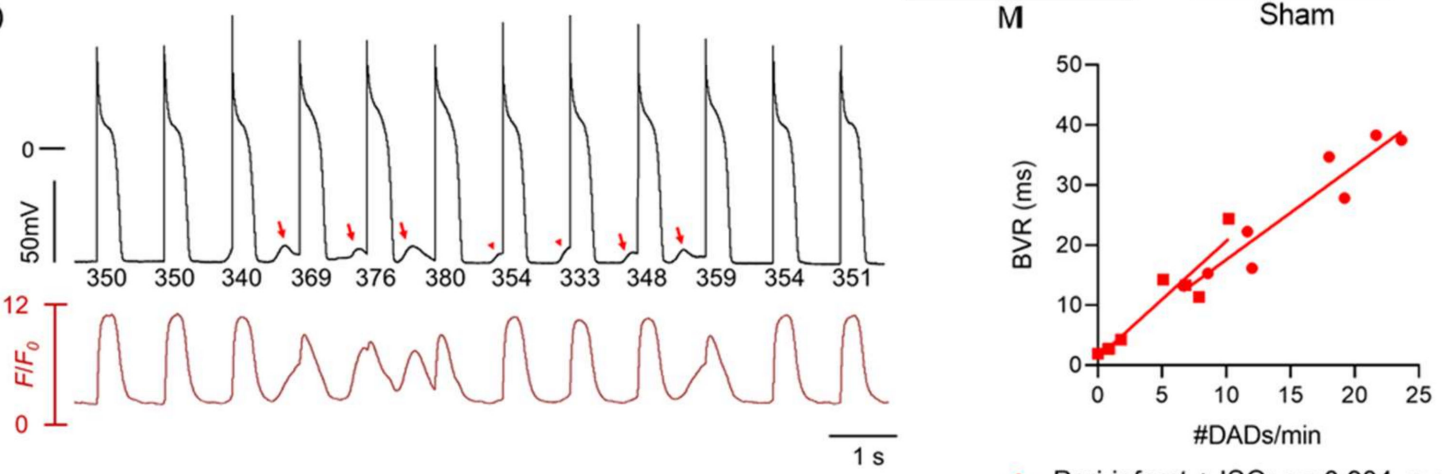

Peri-infarct + ISO: $r=0.904, p<0.001$

Remote + ISO: $r=0.885, p<0.001$

Figure 5. Differential regional remodelling of cardiomyocytes: propensity for DADs and triggered action potentials as well as lability of repolarisation. (A) Resting membrane potential (RMP) of regional isolated cardiomyocytes, border zone (BZ) cardiomyocytes have a more depolarised RMP. (B) Reduced $\mathrm{I}_{\mathrm{K} 1}$ under ISO (isoproterenol) in BZ cardiomyocytes, a contributor to depolarised RMP and propensity for triggered activity. (C) Spontaneous $\mathrm{Ca}^{2+}$ release events and triggered action potentials are increased in MI BZ cardiomyocytes during adrenergic stimulation. (D) Spontaneous $\mathrm{Ca}^{2+}$ release and delayed afterdepolarisations (DADs) influence action potential duration and resultant beat-to-beat variability of repolarisation (BVR). (Adapted from [49,89]). 
Non-myocyte remodelling contributes to the unique nature of the BZ as well. Though beyond the scope of the present review, recent studies are emerging that underscore the diverse nature of cardiac fibroblasts and fibrosis [129,174]. Fibrosis in the BZ may result from the specific myofibroblast phenotype, interacting with its environment, related to unique transcriptomic signatures as seen in pig models of MI [59,175]. Fibroblasts modulate the myocyte electrophysiology and remodelling directly through gap-junctions and through paracrine pathways, in addition to providing a collagen network that interferes with electrical conduction [135,176-179]. MicroRNA signalling from fibroblasts and other cell types is one of the modes of communication [180,181].

In summary, electrical remodelling of myocytes and the heterocellular interactions in the $\mathrm{BZ}$ create a unique environment for arrhythmogenesis, both as a substrate promoting re-entry and as a setting facilitating triggered events. The latter mostly result from an extra stimulus, with a prominent role for altered autonomic drive as initiating event. Hypokalaemia is another example of an initiating event, which would facilitate both trigger and substrate by inducing calcium overload as well as reduce $\mathrm{K}^{+}$currents and destabilise the membrane potential.

\subsection{Role of Autonomic Inputs in the BZ for Arrhythmogenesis}

Inputs from the autonomic nervous system superimpose on the myocyte remodelling to enhance and initiate arrhythmias in several ways [64,182-184].

As mentioned above, innervation within the $\mathrm{BZ}$ is heterogeneous resulting from the denervation-re-innervation sprouting during ischaemia, reperfusion, and recovery. Early experimental studies demonstrated sympathetic innervation to be pro-arrhythmic by enhancement of the substrate by increasing dispersion of repolarisation and triggered activity that is counteracted by the anti-arrhythmic action of the parasympathetic system $[146,185]$.

More recent studies showed that sympathetic stimulation leads to variable AP profiles in subareas of this region, reflecting the variable innervation and related modulatory actions on underlying ion channels and calcium handling $[65,70,186]$. Altered innervation was observed to be linked to increased transmural dispersion of repolarisation due to alterations in transient outward and inward rectifier $\mathrm{K}^{+}$currents $[187,188]$.

Cardiac myocytes have a predominance of beta-adrenergic receptors and circulating catecholamines may also contribute to or superimpose on the vulnerable substrate to promote arrhythmias. Infusion of isoproterenol has been demonstrated to increase dispersion of repolarisation in ICM patients [189]. We recently demonstrated in a pig MI model that adrenergic stimulation increased temporal dispersion, i.e., beat-to-beat variation of repolarisation, which also contributes to the functional substrate [89].

Importantly, increased sympathetic tone is a major factor for initiation of arrhythmias, by generating PVCs. The link between adrenergic-enhanced spontaneous calcium release in myocytes, concurrent depolarisations through the $\mathrm{Na} / \mathrm{Ca}$ exchange currents, and eventually triggered APs is well known [190]. In the BZ, the conditions to translate into a PVC are met including reduced cell-cell coupling, interspersing fibrosis, reduced repolarisation reserve and AP electrical remodelling [191]. Our recent work demonstrated this link (Figure 4), and we could identify preferred sites of PVCs (Figure 6A).

At cellular level, the adrenergic response also reflects changes in the myocyte signalling pathway. Spontaneous calcium release is mediated by $\mathrm{Ca}^{2+}$-calmodulin kinase (CaMK) acting on the RYRs which are differently distributed within the myocytes after MI [89,192]. Moreover, our recent data supports altered response to adrenergic signalling with increased sensitivity in the MI BZ as an underlying mechanism leading to triggered activity in the BZ [49]. Whether this relates to a reduction in receptor density or intracellular signalling is not yet established, but work from Gorelik and her group underscore the changes in receptor localisation and subtypes [193]. 
A Hotspots of triggers for VT
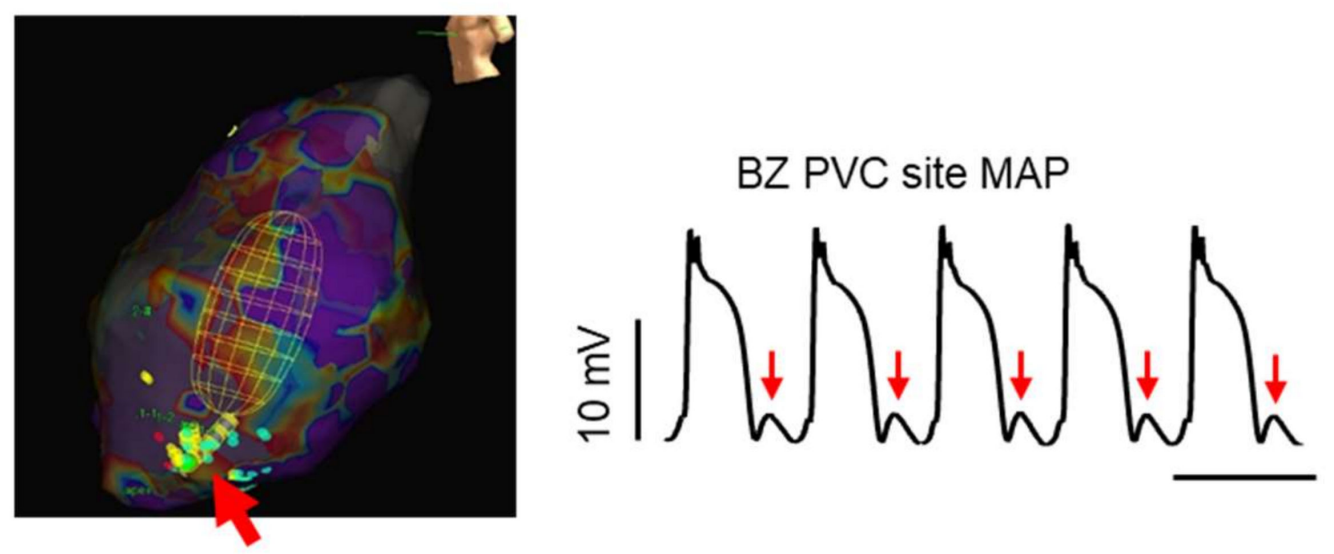

B
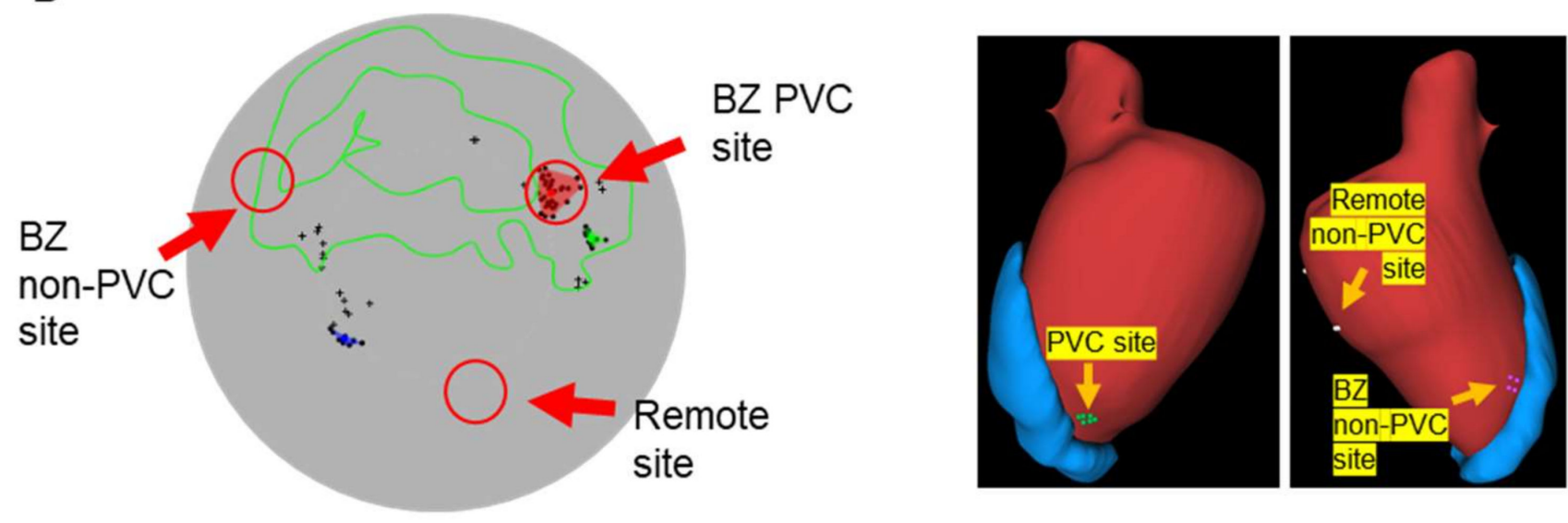

\section{$\Rightarrow$ Targeted sampling of arrhythmogenic sites within the BZ \\ - Local myocyte \& myofibroblast phenotyping \\ - Transcriptomics and epigenetics \\ - Functional cell-cell interaction studies}

Figure 6. Arrhythmia site-directed studies. (A) Left, Electroanatomical mapping of a premature ventricular complex (PVC) preferred site, red arrow (left) and recording of the presence of triggering delayed after depolarisations at this site (right). (B) Corresponding polar map of the spatial localisation of arrhythmogenic and non-arrhythmogenic sites for the electroanatomical map in (A) (left) that can be translated to Imaging-based reconstructions to guide targeted sampling (Adapted from [49]).

The autonomic modulation of arrhythmogenesis has been translated to clinical practice with the established role of first-line beta blockers in the prevention of arrhythmias in postMI patients [16,17]. Neuromodulation is also gaining traction as studies have demonstrated its effectiveness, particularly in treating refractory ventricular tachycardia and arrhythmia storms $[47,194]$.

In summary, the knowledge on cellular mechanisms of arrhythmogenesis in the BZ invites further translational and mechanistic research to improve specific targeting of remodelling in this region. 


\section{Emerging Concepts and Future Research Directions for Post-MI Arrhythmia Management}

\subsection{Systemic Small Molecule Therapy or Local BZ Targeted Therapy}

Small molecules that prevent arrhythmias with clear benefit and few side effects are limited, and none are labelled specifically for post-MI arrhythmias. For atrial fibrillation and certain congenital arrhythmic disorders such as CPVT, research and development of small molecules modulating ion channels and transporters has been converging on $\mathrm{Ca}^{2+}$ handling [195-197]. This seems a valid direction to explore in post-MI arrhythmias as well, as far as triggers are concerned. Increased RYR activity in conditions of adrenergic stress could be mitigated through direct RYR inhibition or through the CaMK signalling pathway. Flecainide has proven its usefulness as an RYR blocker in CPVT [198] but its known proarrhythmia after MI [14], presumably related to $\mathrm{Na}^{+}$channel inhibition, highlights the need for specific and safe RYR blockers. Recent work highlights the potential for modification of flecainide and removal of its Na channel inhibition [199]. Other novel RYR inhibitors have shown promise including the carvedilol derivatives $[200,201]$ as well as tetracaine derivatives [202] and dantrolene derivatives [203] and could open new avenues for more specific targeted pharmacotherapy.

Sufficient first- and second-generation design molecules are becoming available for proof-of-concept testing in vivo in preclinical large-animal models. Whether targeting calcium handling also interferes with re-entry and arrhythmia sustenance is unknown. Lability of repolarisation is typically linked to $\mathrm{K}^{+}$conductances but calcium-dependent changes in membrane currents can contribute as well [204-206]. Given that loss of $\mathrm{K}^{+}$ currents is common, restoring the balance between depolarisation and repolarizing currents is a challenge. $\mathrm{Na} / \mathrm{Ca}$ exchange has proven a difficult target, but the Ca-dependent current mediates delayed afterdepolarisation as well as modulates the APD. Thus, when testing calcium-modulating agents, a comprehensive study of both triggers and substrate is warranted.

A major challenge for small molecule therapy is unwanted off-target effects. As well, heterogeneity of myocyte remodelling within the post-MI heart, and even within the BZ, may not align with systemic pharmacotherapy and calls for identification of suitable targets according to the location within the heart. If a unique signature of myocyte remodelling in culprit lesions could be identified, it would open new perspectives. Given the challenges for systemic pharmacology, local delivery of therapy at arrhythmic sites follows the rationale of local ablation, but without the scar formation. Despite the many hurdles, gene therapy remains an option given a suitable molecular target is identified [207]. Therefore, designing molecular therapy in line with the local mechanisms of arrhythmogenesis in the BZ requires development of more site-directed mechanistic studies (Figure 6B).

Typically, arrhythmogenic areas are identified in vivo during EP studies and recovering them for analysis ex vivo is a challenge. Imaging and computational modelling have greatly helped in identifying arrhythmic sites for ablation, but not yet in marking them for further study. On the other hand, MRI has been used to construct coordinate maps for sampling areas of abnormal contraction [208] and for local injections in the BZ [209,210]. Although these methods are not yet suitable for the recovery of arrhythmogenic sites, a combination of functional EP and MRI could in theory guide ex vivo recovery and allow studies of myocytes, as well as the tissue structure and composition.

Novel methodologies that provide deeper Insights into the local molecular mechanisms will open new perspectives. While physiological measurements at the single cell level are commonplace, only recently have we begun to understand the transcriptomic changes and their underlying regulatory mechanisms in BZ remodelling [211,212]. Transcriptomes generated from tissue is compromised by the mixture of cell types present, which through changes in cell type abundance may mask alterations in gene expression in individual cell types [211]. More recently, strategies to purify individual cardiac cell types have been developed that allow generation of cell type transcriptomes and which can provide insights into mechanisms underlying disease associated phenotypic repro- 
gramming $[213,214]$. However, these analyses do not capture the diversity in phenotypes of cardiomyocytes as well as other cell types that likely arise due to the inhomogeneous cell niche environments present following MI.

\subsection{Understanding the Complexity of the Arrhythmia Sites}

Whereas myocytes are the principle actors of arrhythmias, the tissue complexity within the BZ is key to their function. Not much is known about the role of the myofibroblast/myocyte interactions in the BZ. In situ, connections between myocytes and myofibroblasts can be identified but seem to be rare $[177,179]$. On the other hand, ex vivo, myofibroblasts and myocytes have gap junctional connections that modulate myocyte electrical properties electrotonically. Better imaging in 3D, as currently available after tissue clearing [215], of relevant arrhythmic sites may reveal the network of neurons, myofibroblasts and their myocyte connections [61,216].

Recent advancements in single cell sequencing technology and their application to analysis of cardiac cell types have now begun to shed light on the transcriptional and cellular heterogeneity of the heart $[212,217,218]$. In addition to providing cell-type composition of the tissue analysed, bioinformatic interrogation of these single cell or single nucleus data sets shed light on the differentiation/disease state of the individual cell types and the trajectories taken as the various cell types transition from basal to disease state. Moreover, leveraging databases of cell ligand/receptor pairs and their assignment to the various cell types identified through sequencing, cell-cell interaction networks can be generated $[217,219]$. Exploitation of these identified cell-cell communication networks will yield new molecules that can enhance or prevent cell interactions. In situ transcriptomics is now providing greater context to the relative tissue locations of the cells analysed, thereby complementing more traditional tissue imaging. By in situ transcriptomics, gradients in cell population and phenotypes are identified, which may provide the information necessary to pin-point sites of initiation of arrhythmias within the tissue [212].

Single cell analysis will also contribute to identifying mechanisms by which cell phenotypes are modified in disease. In particular, analysis of the epigenome (DNA methylation, chromatin accessibility, histone modifications) in the same cell as the transcriptome uncovers mechanisms underlying transcriptional regulation including of upstream pathways [220].

Recent advances in preservation and culture of living cardiac slices $[68,221,222]$ will allow testing in the multicellular environment and read-out of myocyte arrhythmogenic properties. As well, they can probe the contributions of cell-cell interactions. Recent data have identified coupling between macrophages and myocytes [223] calling for further studies [224] and methods development that preserve the right environment for study of interactions.

\section{Conclusions}

The management of VT/VF to prevent SCD after myocardial infarction remains challenging and calls for novel mechanistic-based non-invasive treatment.

Identification of the arrhythmia critical sites and characterisation of the molecular signature unique to these sites can open avenues to targeted therapy and reduce off-target effects that have hampered systemic pharmacotherapy. Such advances are in line with precision medicine and a patient-tailored therapy.

Author Contributions: All authors contributed to writing of the manuscript, with M.A. and K.R.S. responsible for conceptualizing and finalizing the manuscript. All authors have read and agreed to the published version of the manuscript.

Funding: This work was supported by the Fund for Scientific Research-Flanders (FWO project grants G.0918.15 and G097021N; Senior Clinical Investigator Fellowship to RW, Senior Postdoctoral Fellowship to ED and Junior Research Fellowship to MA) and by the BOF research fund of KU Leuven (C14/18/079) to RW and PC. 
Institutional Review Board Statement: Not applicable.

Informed Consent Statement: Not applicable.

Data Availability Statement: Not applicable.

Conflicts of Interest: The authors report no conflicts of interest.

\section{References}

1. Timmis, A.; Townsend, N.; Gale, C.P.; Torbica, A.; Lettino, M.; Petersen, S.E.; Mossialos, E.A.; Maggioni, A.P.; Kazakiewicz, D.; May, H.T.; et al. European Society of Cardiology: Cardiovascular Disease Statistics 2019. Eur. Heart J. 2020, 41, 12-85. [CrossRef]

2. Virani, S.S.; Alonso, A.; Benjamin, E.J.; Bittencourt, M.S.; Callaway, C.W.; Carson, A.P.; Chamberlain, A.M.; Chang, A.R.; Cheng, S.; Delling, F.N.; et al. Heart Disease and Stroke Statistics-2020 Update: A Report from the American Heart Association. Circulation 2020, 141, e139-e596. [CrossRef]

3. Berg, D.D.; Wiviott, S.D.; Braunwald, E.; Guo, J.; Im, K.; Kashani, A.; Gibson, C.M.; Cannon, C.P.; Morrow, D.A.; Bhatt, D.L.; et al. Modes and timing of death in 66252 patients with non-ST-segment elevation acute coronary syndromes enrolled in 14 TIMI trials. Eur. Heart J. 2018, 39, 3810-3820. [CrossRef]

4. Grey, C.; Jackson, R.; Schmidt, M.; Ezzati, M.; Asaria, P.; Exeter, D.J.; Kerr, A.J. One in four major ischaemic heart disease events are fatal and 60\% are pre-hospital deaths: A national data-linkage study (ANZACS-QI 8). Eur. Heart J. 2015, 38, 172-180. [CrossRef]

5. Solomon, S.D.; Zelenkofske, S.; Mcmurray, J.; Finn, P.V.; Velazquez, E.; Ertl, G.; Harsanyi, A.; Rouleau, J.L.; Maggioni, A.P.; Kober, L.; et al. Sudden Death in Patients with Myocardial Infarction and Left Ventricular Dysfunction, Heart Failure, or Both. N. Engl. J. Med. 2005, 352, 2581-2588. [CrossRef]

6. Naghavi, M.; Libby, P.; Falk, E.; Casscells, S.W.; Litovsky, S.; Rumberger, J.; Badimon, J.J.; Stefanadis, C.; Moreno, P.; Pasterkamp, G.; et al. From Vulnerable Plaque to Vulnerable Patient: A call for new definitions and risk assessment strategies: Part I. Circulation 2003, 108, 1664-1672. [CrossRef] [PubMed]

7. Braunwald, E. Cardiovascular Medicine at the Turn of the Millennium: Triumphs, Concerns, and Opportunities. N. Engl. J. Med. 1997, 337, 1360-1369. [CrossRef] [PubMed]

8. Armstrong, P.; Gershlick, A.H.; Goldstein, P.; Wilcox, R.; Danays, T.; Lambert, Y.; Sulimov, V.; Rosell-Ortiz, F.; Ostojic, M.; Welsh, R.; et al. Fibrinolysis or Primary PCI in ST-Segment Elevation Myocardial Infarction. N. Engl. J. Med. 2013, 368, $1379-1387$. [CrossRef] [PubMed]

9. Dan, G.-A.; Martinez-Rubio, A.; Agewall, S.; Boriani, G.; Borggrefe, M.; Gaita, F.; Van Gelder, I.; Gorenek, B.; Kaski, J.C.; Kjeldsen, K.; et al. Antiarrhythmic drugs-clinical use and clinical decision making: A consensus document from the European Heart Rhythm Association (EHRA) and European Society of Cardiology (ESC) Working Group on Cardiovascular Pharmacology, endorsed by the Heart Rhythm Society (HRS), Asia-Pacific Heart Rhythm Society (APHRS) and International Society of Cardiovascular Pharmacotherapy (ISCP). EP Eur. 2018, 20, 731-732. [CrossRef]

10. Amsterdam, E.A.; Wenger, N.K.; Brindis, R.G.; Casey, D.; Ganiats, T.G.; Holmes, D.R.; Jaffe, A.S.; Jneid, H.; Kelly, R.F.; Kontos, M.C.; et al. 2014 AHA/ACC Guideline for the Management of Patients with Non-ST-Elevation Acute Coronary Syndromes: Executive Summary. Circulation 2014, 130, 2354-2394. [CrossRef] [PubMed]

11. Levine, G.N.; Bates, E.R.; Blankenship, J.C.; Bailey, S.R.; Bittl, J.A.; Cercek, B.; Chambers, C.E.; Ellis, S.G.; Guyton, R.A.; Hollenberg, S.M.; et al. 2015 ACC/AHA/SCAI Focused Update on Primary Percutaneous Coronary Intervention for Patients with ST-Elevation Myocardial Infarction: An Update of the 2011 ACCF/AHA/SCAI Guideline for Percutaneous Coronary Intervention and the 2013 ACCF/AHA Guideline for the Management of ST-Elevation Myocardial Infarction. J. Am. Coll. Cardiol. 2016, 67, 1235-1250. [CrossRef] [PubMed]

12. Mehta, D.; Curwin, J.; Gomes, J.A.; Fuster, V. Sudden death in coronary artery disease: Acute ischemia versus myocardial substrate. Circulation 1997, 96, 3215-3223. [CrossRef] [PubMed]

13. Davidson, S.M.; Ferdinandy, P.; Andreadou, I.; Botker, H.E.; Heusch, G.; Ibanez, B.; Ovize, M.; Schulz, R.; Yellon, D.M.; Hausenloy, D.J.; et al. Multitarget Strategies to Reduce Myocardial Ischemia/Reperfusion Injury: JACC Review Topic of the Week. J. Am. Coll. Cardiol. 2019, 73, 89-99. [CrossRef]

14. Echt, D.S.; Liebson, P.R.; Mitchell, L.B.; Peters, R.W.; Obias-Manno, D.; Barker, A.H.; Arensberg, D.; Baker, A.; Friedman, L.; Greene, H.L.; et al. Mortality and morbidity in patients receiving encainide, flecainide, or placebo. The Cardiac Arrhythmia Suppression Trial. N. Engl. J. Med. 1991, 324, 781-788. [CrossRef] [PubMed]

15. Waldo, A.L.; Camm, A.J.; Deruyter, H.; Friedman, P.L.; MacNeil, D.J.; Pauls, J.F.; Pitt, B.; Pratt, C.M.; Schwartz, P.J.; Veltri, E.P. Effect of d-sotalol on mortality in patients with left ventricular dysfunction after recent and remote myocardial infarction. Lancet 1996, 348, 7-12. [CrossRef]

16. Al-Khatib, S.M.; Stevenson, W.G.; Ackerman, M.J.; Bryant, W.J.; Callans, D.J.; Curtis, A.B.; Deal, B.J.; Dickfeld, T.; Field, M.E.; Fonarow, G.C.; et al. 2017 AHA/ACC/HRS guideline for management of patients with ventricular arrhythmias and the prevention of sudden cardiac death: Executive summary. Heart Rhythm. 2018, 15, e190-e252. [CrossRef]

17. Al-Gobari, M.; El Khatib, C.; Pillon, F.; Gueyffier, F. Beta-blockers for the prevention of sudden cardiac death in heart failure patients: A meta-analysis of randomized controlled trials. BMC Cardiovasc. Disord. 2013, 13, 1-52. [CrossRef] [PubMed] 
18. Viskin, S.; Chorin, E.; Viskin, D.; Hochstadt, A.; Halkin, A.; Tovia-Brodie, O.; Lee, J.K.; Asher, E.; Laish-Farkash, A.; Amit, G.; et al. Quinidine-Responsive Polymorphic Ventricular Tachycardia in Patients with Coronary Heart Disease. Circulation 2019, 139, 2304-2314. [CrossRef]

19. Zabel, M.; Willems, R.; Lubinski, A.; Bauer, A.; Brugada, J.; Conen, D.; Flevari, P.; Hasenfuß, G.; Svetlosak, M.; Huikuri, H.V.; et al. Clinical effectiveness of primary prevention implantable cardioverter-defibrillators: Results of the EU-CERT-ICD controlled multicentre cohort study. Eur. Heart J. 2020, 41, 3437-3447. [CrossRef]

20. Myerburg, R.J.; Junttila, M.J. Sudden Cardiac Death Caused by Coronary Heart Disease. Circulation 2012, 125, 1043-1052. [CrossRef]

21. Chatterjee, N.A.; Moorthy, M.V.; Pester, J.; Schaecter, A.; Panicker, G.K.; Narula, D.; Lee, D.; Goldberger, J.J.; Kadish, A.; Cook, N.R.; et al. Sudden Death in Patients with Coronary Heart Disease without Severe Systolic Dysfunction. JAMA Cardiol. 2018, 3, 591-600. [CrossRef]

22. Priori, S.; Blomström-Lundqvist, C.; Mazzanti, A.; Blom, N.A.; Borggrefe, M.; Camm, J.; Elliott, P.; Fitzsimons, D.; Hatala, R.; Hindricks, G.; et al. 2015 ESC Guidelines for the management of patients with ventricular arrhythmias and the prevention of sudden cardiac death. Eur. Heart J. 2015, 36, 2793-2867. [CrossRef]

23. Pedersen, C.T.; Kay, G.N.; Kalman, J.; Borggrefe, M.; Della-Bella, P.; Dickfeld, T.; Dorian, P.; Huikuri, H.; Kim, Y.-H.; Knight, B.; et al. EHRA/HRS/APHRS Expert Consensus on Ventricular Arrhythmias. Heart Rhythm. 2014, 11, e166-e196. [CrossRef]

24. Buxton, A.E.; Lee, K.L.; Dicarlo, L.; Gold, M.R.; Greer, G.S.; Prystowsky, E.N.; O’Toole, M.F.; Tang, A.; Fisher, J.; Coromilas, J.; et al. Electrophysiologic Testing to Identify Patients with Coronary Artery Disease Who Are at Risk for Sudden Death. N. Engl. J. Med. 2000, 342, 1937-1945. [CrossRef]

25. Daubert, J.P.; Zareba, W.; Hall, W.J.; Schuger, C.; Corsello, A.; Leon, A.R.; Andrews, M.L.; McNitt, S.; Huang, D.T.; Moss, A.J. Predictive Value of Ventricular Arrhythmia Inducibility for Subsequent Ventricular Tachycardia or Ventricular Fibrillation in Multicenter Automatic Defibrillator Implantation Trial (MADIT) II Patients. J. Am. Coll. Cardiol. 2006, 47, 98-107. [CrossRef]

26. Wellens, H.J.J.; Schwartz, P.J.; Lindemans, F.W.; Buxton, A.E.; Goldberger, J.J.; Hohnloser, S.H.; Huikuri, H.V.; Kaab, S.; La Rovere, M.T.; Malik, M.; et al. Risk stratification for sudden cardiac death: Current status and challenges for the future. Eur. Heart J. 2014, 35, 1642-1651. [CrossRef] [PubMed]

27. Nielsen, J.C.; Lin, Y.; Figueiredo, M.J.D.O.; Shamloo, A.S.; Alfie, A.; Boveda, S.; Dagres, N.; Di Toro, D.; Eckhardt, L.L.; Ellenbogen, K.; et al. European Heart Rhythm Association (EHRA)/Heart Rhythm Society (HRS)/Asia Pacific Heart Rhythm Society (APHRS)/Latin American Heart Rhythm Society (LAHRS) expert consensus on risk assessment in cardiac arrhythmias: Use the right tool for the right outcome, in the right population. J. Arrhythmia 2020, 36, 553-607. [CrossRef]

28. Schmidt, A.; Azevedo, C.F.; Cheng, A.; Gupta, S.N.; Bluemke, D.; Foo, T.K.; Gerstenblith, G.; Weiss, R.G.; Marbán, E.; Tomaselli, G.F.; et al. Infarct Tissue Heterogeneity by Magnetic Resonance Imaging Identifies Enhanced Cardiac Arrhythmia Susceptibility in Patients with Left Ventricular Dysfunction. Circulation 2007, 115, 2006-2014. [CrossRef]

29. Reichlin, T.; Asatryan, B.; Vos, M.A.; Willems, R.; Huikuri, H.V.; Junttila, M.J.; Schlögl, S.C.; Hnatkova, K.; Schaer, B.A.; Malik, M.; et al. Automated electrocardiographic quantification of myocardial scar in patients undergoing primary prevention implantable cardioverter-defibrillator implantation: Association with mortality and subsequent appropriate and inappropriate therapies. Heart Rhythm. 2020, 17, 1664-1671. [CrossRef] [PubMed]

30. Goldberger, J.J.; Cain, M.E.; Hohnloser, S.H.; Kadish, A.H.; Knight, B.P.; Lauer, M.S.; Maron, B.J.; Page, R.L.; Passman, R.S.; Siscovick, D.; et al. American Heart Association/American College of Cardiology Foundation/Heart Rhythm Society Scientific Statement on Noninvasive Risk Stratification Techniques for Identifying Patients at Risk for Sudden Cardiac Death: A Scientific Statement From the American Heart Association Council on Clinical Cardiology Committee on Electrocardiography and Arrhythmias and Council on Epidemiology and Prevention. J. Am. Coll. Cardiol. 2008, 52, 1179-1199. [CrossRef] [PubMed]

31. De Sousa, M.R.; Morillo, C.A.; Rabelo, F.T.; Filho, A.M.N.; Ribeiro, A. Non-sustained ventricular tachycardia as a predictor of sudden cardiac death in patients with left ventricular dysfunction: A meta-analysis. Eur. J. Heart Fail. 2008, 10, 1007-1014. [CrossRef]

32. Bauer, A.; Klemm, M.; Rizas, K.; Hamm, W.; von Stülpnagel, L.; Dommasch, M.; Steger, A.; Lubinski, A.; Flevari, P.; Harden, M.; et al. Prediction of mortality benefit based on periodic repolarisation dynamics in patients undergoing prophylactic implantation of a defibrillator: A prospective, controlled, multicentre cohort study. Lancet 2019, 394, $1344-1351$. [CrossRef]

33. Seegers, J.; Bergau, L.; Expósito, P.M.; Bauer, A.; Fischer, T.H.; Lüthje, L.; Hasenfuß, G.; Friede, T.; Zabel, M. Prediction of Appropriate Shocks Using 24-Hour Holter Variables and T-Wave Alternans After First Implantable Cardioverter-Defibrillator Implantation in Patients with Ischemic or Nonischemic Cardiomyopathy. Am. J. Cardiol. 2016, 118, 86-94. [CrossRef] [PubMed]

34. Amoni, M.; Vandenberk, B.; Moeyersons, J.; Van Huffel, S.; Sipido, K.R.; Willems, R. Temporal beat-to-beat variability of repolarizationTemporal beat-to-beat variability of repolarization (BVR) changes predict imminent non-sustained ventricular tachycardia in ischaemic heart disease patients. Europace 2018, 20, i41. [CrossRef]

35. Smoczyńska, A.; Loen, V.; Sprenkeler, D.J.; Tuinenburg, A.E.; Van Eck, H.J.R.; Malik, M.; Schmidt, G.; Meine, M.; Vos, M.A. Short-Term Variability of the QT Interval Can be Used for the Prediction of Imminent Ventricular Arrhythmias in Patients with Primary Prophylactic Implantable Cardioverter Defibrillators. J. Am. Heart Assoc. 2020, 9, e018133. [CrossRef] [PubMed] 
36. Vandenberk, B.; Junttila, M.J.; Robyns, T.; Garweg, C.; Ector, J.; Huikuri, H.V.; Willems, R. Combining noninvasive risk stratification parameters improves the prediction of mortality and appropriate ICD shocks. Ann. Noninvasive Electrocardiol. 2018, 24, e12604. [CrossRef] [PubMed]

37. Chatterjee, N.A.; Tikkanen, J.T.; Panicker, G.K.; Narula, D.; Lee, D.C.; Kenttä, T.; Junttila, J.M.; Cook, N.R.; Kadish, A.; Goldberger, J.J.; et al. Simple electrocardiographic measures improve sudden arrhythmic death prediction in coronary disease. Eur. Heart J. 2020, 41, 1988-1999. [CrossRef]

38. Verstraelen, T.E.; van Barreveld, M.; van Dessel, P.H.F.M.; Boersma, L.V.A.; Delnoy, P.-P.P.H.M.; Tuinenburg, A.E.; Theuns, D.A.M.J.; van der Voort, P.H.; Kimman, G.P.; Buskens, E.; et al. Development and external validation of prediction models to predict implantable cardioverter-defibrillator efficacy in primary prevention of sudden cardiac death. EP Eur. 2021, 23, 887-897. [CrossRef]

39. Li, A.; Kaura, A.; Sunderland, N.; Dhillon, P.S.; Scott, P.A. The Significance of Shocks in Implantable Cardioverter Defibrillator Recipients. Arrhythmia Electrophysiol. Rev. 2016, 5, 110-116. [CrossRef]

40. Mitchell, L.; Pineda, E.A.; Titus, J.L.; Bartosch, P.M.; Benditt, D.G. Sudden death in patients with implantable cardioverter defibrillators: The importance of post-shock electromechanical dissociation. J. Am. Coll. Cardiol. 2002, 39, 1323-1328. [CrossRef]

41. Thylén, I.; Moser, D.K.; Strömberg, A.; Dekker, R.A.; Chung, M.L. Concerns about implantable cardioverter-defibrillator shocks mediate the relationship between actual shocks and psychological distress. Europace 2016, 18, 828-835. [CrossRef]

42. Cronin, E.M.; Bogun, F.M.; Maury, P.; Peichl, P.; Chen, M.; Namboodiri, N.; Aguinaga, L.; Leite, L.R.; Al-Khatib, S.M.; Anter, E.; et al. 2019 HRS/EHRA/APHRS/LAHRS expert consensus statement on catheter ablation of ventricular arrhythmias: Executive summary. Europace 2020, 22, 450-495. [CrossRef]

43. Sapp, J.L.; Wells, G.A.; Parkash, R.; Stevenson, W.G.; Blier, L.; Sarrazin, J.-F.; Thibault, B.; Rivard, L.; Gula, L.; Leong-Sit, P.; et al. Ventricular Tachycardia Ablation versus Escalation of Antiarrhythmic Drugs. N. Engl. J. Med. 2016, 375, 111-121. [CrossRef]

44. Sadek, M.M.; Schaller, R.D.; Supple, G.E.; Frankel, D.S.; Riley, M.P.; Hutchinson, M.D.; Garcia, F.C.; Lin, D.; Dixit, S.; Zado, E.S.; et al. Ventricular Tachycardia Ablation-The Right Approach for the Right Patient. Arrhythmia Electrophysiol. Rev. 2014, 3, 161-167. [CrossRef]

45. Baldinger, S.H.; Stevenson, W.G.; John, R.M. Ablation of ischemic ventricular tachycardia: Evidence, techniques, results, and future directions. Curr. Opin. Cardiol. 2016, 31, 29-36. [CrossRef] [PubMed]

46. Vaseghi, M.; Barwad, P.; Corrales, F.J.M.; Tandri, H.; Mathuria, N.; Shah, R.; Sorg, J.M.; Gima, J.; Mandal, K.; Morales, L.C.S.; et al. Cardiac Sympathetic Denervation for Refractory Ventricular Arrhythmias. J. Am. Coll. Cardiol. 2017, 69, 3070-3080. [CrossRef] [PubMed]

47. Meng, L.; Tseng, C.-H.; Shivkumar, K.; Ajijola, O. Efficacy of Stellate Ganglion Blockade in Managing Electrical Storm. A Systematic Review. JACC Clin. Electrophysiol. 2017, 3, 942-949. [CrossRef] [PubMed]

48. Frangogiannis, N.G. Regulation of the Inflammatory Response in Cardiac Repair. Circ. Res. 2012, 110, 159-173. [CrossRef] [PubMed]

49. Amoni, M.; Claus, P.; Dries, E.; Nagaraju, C.; De Buck, S.; Vandenberk, B.; Ingelaere, S.; Vermoortele, D.; Roderick, H.L.; Sipido, K.R.; et al. Discrete sites of frequent premature ventricular complexes cluster within the infarct border zone and coincide with high frequency of delayed afterdepolarizations under adrenergic stimulation. Heart Rhythm. 2021, 7, 67. [CrossRef]

50. Daseke, M.J.; Chalise, U.; Becirovic-Agic, M.; Salomon, J.D.; Cook, L.M.; Case, A.J.; Lindsey, M.L. Neutrophil signaling during myocardial infarction wound repair. Cell. Signal. 2021, 77, 109816. [CrossRef]

51. Ma, Y.; Mouton, A.J.; Lindsey, M.L. Cardiac macrophage biology in the steady-state heart, the aging heart, and following myocardial infarction. Transl. Res. 2018, 191, 15-28. [CrossRef]

52. Rossello, X.; Yellon, D.M. The RISK pathway and beyond. Basic Res. Cardiol. 2018, 113, 1-5. [CrossRef]

53. Hadebe, N.; Cour, M.; Lecour, S. The SAFE pathway for cardioprotection: Is this a promising target? Basic Res. Cardiol. 2018, 113, 9. [CrossRef]

54. Opie, L.H.; Commerford, P.J.; Gersh, B.J.; Pfeffer, M.A. Controversies in ventricular remodelling. Lancet 2006, 367, 356-367. [CrossRef]

55. Ashikaga, H.; Mickelsen, S.R.; Ennis, D.B.; Rodriguez, I.; Kellman, P.; Wen, H.; McVeigh, E.R. Electromechanical analysis of infarct border zone in chronic myocardial infarction. Am. J. Physiol. Circ. Physiol. 2005, 289, H1099-H1105. [CrossRef] [PubMed]

56. Jackson, B.M.; Gorman, J.H.; Salgo, I.S.; Moainie, S.L.; Plappert, T.; John-Sutton, M.S.; Edmunds, L.H.; Gorman, R.C. Border zone geometry increases wall stress after myocardial infarction: Contrast echocardiographic assessment. Am. J. Physiol. Circ. Physiol. 2003, 284, H475-H479. [CrossRef] [PubMed]

57. Frisk, M.; Ruud, M.; Espe, E.K.S.; Aronsen, J.M.; Røe, Å.T.; Zhang, L.; Norseng, P.A.; Sejersted, O.M.; Christensen, G.A.; Sjaastad, I.; et al. Elevated ventricular wall stress disrupts cardiomyocyte t-tubule structure and calcium homeostasis. Cardiovasc. Res. 2016, 112, 443-451. [CrossRef] [PubMed]

58. Galan, D.T.; Bito, V.; Claus, P.; Holemans, P.; Abi-Char, J.; Nagaraju, C.K.; Dries, E.; Vermeulen, K.; Ventura-Clapier, R.; Sipido, K.R.; et al. Reduced mitochondrial respiration in the ischemic as well as in the remote nonischemic region in postmyocardial infarction remodeling. Am. J. Physiol. Circ. Physiol. 2016, 311, H1075-H1090. [CrossRef] [PubMed]

59. Nagaraju, C.K.; Dries, E.; Popovic, N.; Singh, A.; Haemers, P.; Roderick, H.; Claus, P.; Sipido, K.R.; Driesen, R.B. Global fibroblast activation throughout the left ventricle but localized fibrosis after myocardial infarction. Sci. Rep. 2017, 7, 1-14. [CrossRef] [PubMed] 
60. Cox, M.M.; Berman, I.; Myerburg, R.J.; Smets, M.J.; Kozlovskis, P.L. Morphometric mapping of regional myocyte diameters after healing of myocardial infarction in cats. J. Mol. Cell. Cardiol. 1991, 23, 127-135. [CrossRef]

61. Yokoyama, T.; Lee, J.-K.; Miwa, K.; Opthof, T.; Tomoyama, S.; Nakanishi, H.; Yoshida, A.; Yasui, H.; Iida, T.; Miyagawa, S.; et al. Quantification of sympathetic hyperinnervation and denervation after myocardial infarction by three-dimensional assessment of the cardiac sympathetic network in cleared transparent murine hearts. PLoS ONE 2017, 12, e0182072. [CrossRef]

62. Matsunari, I.; Schricke, U.; Bengel, F.M.; Haase, H.-U.; Barthel, P.; Schmidt, G.; Nekolla, S.G.; Schoemig, A.; Schwaiger, M. Extent of cardiac sympathetic neuronal damage is determined by the area of ischemia in patients with acute coronary syndromes. Circulation 2000, 101, 2579-2585. [CrossRef]

63. Cao, J.-M.; Fishbein, M.C.; Han, J.B.; Lai, W.W.; Lai, A.C.; Wu, T.-J.; Czer, L.; Wolf, P.L.; Denton, T.A.; Shintaku, I.P.; et al. Relationship between regional cardiac hyperinnervation and ventricular arrhythmia. Circulation 2000, 101, 1960-1969. [CrossRef]

64. Rajendran, P.S.; Nakamura, K.; Ajijola, O.; Vaseghi, M.; Armour, J.A.; Ardell, J.L.; Shivkumar, K. Myocardial infarction induces structural and functional remodelling of the intrinsic cardiac nervous system. J. Physiol. 2015, 594, 321-341. [CrossRef]

65. Gardner, R.T.; Wang, L.; Lang, B.T.; Cregg, J.M.; Dunbar, C.L.; Woodward, W.R.; Silver, J.; Ripplinger, C.M.; Habecker, B.A. Targeting protein tyrosine phosphatase $\sigma$ after myocardial infarction restores cardiac sympathetic innervation and prevents arrhythmias. Nat. Commun. 2015, 6, 6235. [CrossRef]

66. Zhou, S.; Chen, L.S.; Miyauchi, Y.; Miyauchi, M.; Kar, S.; Kangavari, S.; Fishbein, M.C.; Sharifi, B.; Chen, P.-S. Mechanisms of Cardiac Nerve Sprouting After Myocardial Infarction in Dogs. Circ. Res. 2004, 95, 76-83. [CrossRef]

67. Habecker, B.A.; Anderson, M.E.; Birren, S.J.; Fukuda, K.; Herring, N.; Hoover, D.B.; Kanazawa, H.; Paterson, D.J.; Ripplinger, C. Molecular and cellular neurocardiology: Development, and cellular and molecular adaptations to heart disease. J. Physiol. 2016, 594, 3853-3875. [CrossRef] [PubMed]

68. Wang, K.; Lee, P.; Mirams, G.R.; Sarathchandra, P.; Borg, T.K.; Gavaghan, D.J.; Kohl, P.; Bollensdorff, C. Cardiac tissue slices: Preparation, handling, and successful optical mapping. Am. J. Physiol. Circ. Physiol. 2015, 308, H1112-H1125. [CrossRef] [PubMed]

69. Ajijola, O.; Yagishita, D.; Patel, K.J.; Vaseghi, M.; Zhou, W.; Yamakawa, K.; So, E.; Lux, R.L.; Mahajan, A.; Shivkumar, K. Focal myocardial infarction induces global remodeling of cardiac sympathetic innervation: Neural remodeling in a spatial context. Am. J. Physiol. Circ. Physiol. 2013, 305, H1031-H1040. [CrossRef] [PubMed]

70. Ajijola, O.A.; Yagishita, D.; Reddy, N.K.; Yamakawa, K.; Vaseghi, M.; Downs, A.M.; Hoover, D.B.; Ardell, J.L.; Shivkumar, K. Remodeling of stellate ganglion neurons after spatially targeted myocardial infarction: Neuropeptide and morphologic changes. Heart Rhythm. 2015, 12, 1027-1035. [CrossRef] [PubMed]

71. Han, S.; Kobayashi, K.; Joung, B.; Piccirillo, G.; Maruyama, M.; Vinters, H.V.; March, K.; Lin, S.-F.; Shen, C.; Fishbein, M.C.; et al. Electroanatomic Remodeling of the Left Stellate Ganglion After Myocardial Infarction. J. Am. Coll. Cardiol. 2012, 59, 954-961. [CrossRef]

72. Padro, T.; Manfrini, O.; Bugiardini, R.; Canty, J.; Cenko, E.; De Luca, G.; Duncker, D.J.; Eringa, E.C.; Koller, A.; Tousoulis, D.; et al. ESC Working Group on Coronary Pathophysiology and Microcirculation position paper on 'coronary microvascular dysfunction in cardiovascular disease' . Cardiovasc. Res. 2020, 116, 741-755. [CrossRef]

73. Robbers, L.F.; Eerenberg, E.S.; Teunissen, P.F.; Jansen, M.F.; Hollander, M.R.; Horrevoets, A.J.; Knaapen, P.; Nijveldt, R.; Heymans, M.W.; Levi, M.M.; et al. Magnetic resonance imaging-defined areas of microvascular obstruction after acute myocardial infarction represent microvascular destruction and haemorrhage. Eur. Heart J. 2013, 34, 2346-2353. [CrossRef]

74. van der Burg, A.E.B.; Bax, J.J.; Boersma, E.; Pauwels, E.K.; van der Wall, E.E.; Schalij, M.J. Impact of Viability, Ischemia, Scar Tissue, and Revascularization on Outcome After Aborted Sudden Death. Circulation 2003, 108, 1954-1959. [CrossRef]

75. Travin, M.I.; Dessouki, A.; Cameron, T.; Helle, G.V. Use of exercise technetiumtium-99m sestamibi SPECT imagina to detect residual ischemia and for risk stratification after acute myocardial infarction. Am. J. Cardiol. 1995, 75, 665-669. [CrossRef]

76. Wu, X.; Reboll, M.R.; Korf-Klingebiel, M.; Wollert, K.C. Angiogenesis after acute myocardial infarction. Cardiovasc. Res. 2021, 117, 1257-1273. [CrossRef] [PubMed]

77. Merkus, D.; Muller-Delp, J.; Heaps, C.L. Coronary microvascular adaptations distal to epicardial artery stenosis. Am. J. Physiol. Circ. Physiol. 2021, 320, H2351-H2370. [CrossRef] [PubMed]

78. Kalkman, E.A.; Van Haren, P.; Saxena, P.R.; Schoemaker, R.G. Regionally Different Vascular Response to Vasoactive Substances in the Remodelled Infarcted Rat Heart; Aberrant Vasculature in the Infarct Scar. J. Mol. Cell. Cardiol. 1997, 29, 1487-1497. [CrossRef] [PubMed]

79. Sellke, F.W.; Kagaya, Y.; Johnson, R.G.; Shafique, T.; Schoen, F.J.; Grossman, W.; Weintraub, R.M. Endothelial modulation of porcine coronary microcirculation perfused via immature collaterals. Am. J. Physiol. Circ. Physiol. 1992, 262, H1669-H1675. [CrossRef] [PubMed]

80. Gorenek, B.; Cengiz, O.; Kudaiberdieva, G.; Durak, I.; Dogan, V.; Yasar, B.; Birdane, A.; Cavusoglu, Y.; Ata, N. Mode of onset of polymorphic ventricular tachycardia in acute myocardial infarction. Can. J. Cardiol. 2010, 26, e254-e257. [CrossRef]

81. Lerma, C.; Gorelick, A.; Ghanem, R.N.; Glass, L.; Huikuri, H.V. Patterns of ectopy leading to increased risk of fatal or near-fatal cardiac arrhythmia in patients with depressed left ventricular function after an acute myocardial infarction. EP Eur. 2013, 15, 1304-1312. [CrossRef] 
82. Janse, M.J.; van Capelle, F.J.; Morsink, H.; Kléber, A.G.; Wilms-Schopman, F.; Cardinal, R.; D'Alnoncourt, C.N.; Durrer, D. Flow of "injury" current and patterns of excitation during early ventricular arrhythmias in acute regional myocardial ischemia in isolated porcine and canine hearts. Evidence for two different arrhythmogenic mechanisms. Circ. Res. 1980, 47, 151-165. [CrossRef]

83. Szumowski, L.; Sanders, P.; Walczak, F.; Hocini, M.; Jaïs, P.; Kepski, R.; Szufladowicz, E.; Urbanek, P.; Derejko, P.; Bodalski, R.; et al. Mapping and ablation of polymorphic ventricular tachycardia after myocardial infarction. J. Am. Coll. Cardiol. 2004, 44, 1700-1706. [CrossRef]

84. Xing, D.; Martins, J.B. Triggered activity due to delayed afterdepolarizations in sites of focal origin of ischemic ventricular tachycardia. Am. J. Physiol. Circ. Physiol. 2004, 287, H2078-H2084. [CrossRef] [PubMed]

85. Volders, P.G.; Vos, M.A.; Szabo, B.; Sipido, K.R.; De Groot, S.; Gorgels, A.P.; Wellens, H.J.; Lazzara, R. Progress in the understanding of cardiac early afterdepolarizations and torsades de pointes: Time to revise current concepts. Cardiovasc. Res. 2000, 46, 376-392. [CrossRef]

86. Wit, A.L. Afterdepolarizations and triggered activity as a mechanism for clinical arrhythmias. Pacing Clin. Electrophysiol. 2018, 41, 883-896. [CrossRef] [PubMed]

87. Janse, M.J.; Wit, A.L. Electrophysiological mechanisms of ventricular arrhythmias resulting from myocardial ischemia and infarction. Physiol. Rev. 1989, 69, 1049-1169. [CrossRef]

88. Hegyi, B.; Bossuyt, J.; Griffiths, L.G.; Shimkunas, R.; Coulibaly, Z.; Jian, Z.; Grimsrud, K.N.; Sondergaard, C.S.; Ginsburg, K.S.; Chiamvimonvat, N.; et al. Complex electrophysiological remodeling in postinfarction ischemic heart failure. Proc. Natl. Acad. Sci. USA 2018, 115, E3036-E3044. [CrossRef]

89. Dries, E.; Amoni, M.; Vandenberk, B.; Johnson, D.M.; Gilbert, G.; Nagaraju, C.K.; Puertas, R.D.; Abdesselem, M.; Santiago, D.J.; Roderick, H.L.; et al. Altered adrenergic response in myocytes bordering a chronic myocardial infarction underlies in vivo triggered activity and repolarization instability. J. Physiol. 2020, 598, 2875-2895. [CrossRef] [PubMed]

90. Trayanova, N.A.; Doshi, A.N.; Prakosa, A. How personalized heart modeling can help treatment of lethal arrhythmias: A focus on ventricular tachycardia ablation strategies in post-infarction patients. WIREs Syst. Biol. Med. 2020, 12, e1477. [CrossRef]

91. de Barros, B.G.; dos Santos, R.W.; Lobosco, M.; Alonso, S. Simulation of Ectopic Pacemakers in the Heart: Multiple Ectopic Beats Generated by Reentry inside Fibrotic Regions. BioMed Res. Int. 2015, 2015, 1-18. [CrossRef]

92. Oliveira, R.S.; Alonso, S.; Campos, F.O.; Rocha, B.M.; Fernandes, J.F.; Kuehne, T.; Dos Santos, R.W. Ectopic beats arise from micro-reentries near infarct regions in simulations of a patient-specific heart model. Sci. Rep. 2018, 8, 1-14. [CrossRef]

93. Haemers, P.; Sutherland, G.R.; Cikes, M.; Jakus, N.; Holemans, P.; Sipido, K.R.; Willems, R.; Claus, P. Further insights into blood pressure induced premature beats: Transient depolarizations are associated with fast myocardial deformation upon pressure decline. Heart Rhythm. 2015, 12, 2305-2315. [CrossRef]

94. Johnson, D.M.; Antoons, G. Arrhythmogenic Mechanisms in Heart Failure: Linking $\beta$-Adrenergic Stimulation, Stretch, and Calcium. Front. Physiol. 2018, 9, 1453. [CrossRef]

95. Ravens, U. Mechano-electric feedback and arrhythmias. Prog. Biophys. Mol. Biol. 2003, 82, 255-266. [CrossRef]

96. Taggart, P.; Sutton, P.M. Cardiac mechano-electric feedback in man: Clinical relevance. Prog. Biophys. Mol. Biol. 1999, 71, 139-154. [CrossRef]

97. De Bakker, J.M.; Van Capelle, F.J.; Janse, M.J.; Tasseron, S.; Vermeulen, J.T.; De Jonge, N.; Lahpor, J.R. Slow conduction in the infarcted human heart. 'Zigzag' course of activation. Circulation 1993, 88, 915-926. [CrossRef]

98. Ciaccio, E.J.; Coromilas, J.; Wit, A.L.; Peters, N.S.; Garan, H. Formation of Functional Conduction Block During the Onset of Reentrant Ventricular Tachycardia. Circ. Arrhythmia Electrophysiol. 2016, 9, e004462. [CrossRef] [PubMed]

99. Baba, S.; Dun, W.; Cabo, C.; Boyden, P.A. Remodeling in cells from different regions of the reentrant circuit during ventricular tachycardia. Circulation 2005, 112, 2386-2396. [CrossRef] [PubMed]

100. Restivo, M.; Gough, W.B.; El-Sherif, N. Ventricular arrhythmias in the subacute myocardial infarction period. High-resolution activation and refractory patterns of reentrant rhythms. Circ. Res. 1990, 66, 1310-1327. [CrossRef]

101. Qin, D.; Zhang, Z.-H.; Caref, E.B.; Boutjdir, M.; Jain, P.; El-Sherif, N. Cellular and Ionic Basis of Arrhythmias in Postinfarction Remodeled Ventricular Myocardium. Circ. Res. 1996, 79, 461-473. [CrossRef] [PubMed]

102. Orini, M.; Taggart, P.; Bhuva, A.; Roberts, N.; Di Salvo, C.; Yates, M.; Badiani, S.; Van Duijvenboden, S.; Lloyd, G.; Smith, A.; et al. Direct in vivo assessment of global and regional mechanoelectric feedback in the intact human heart. Heart Rhythm. 2021, 18, 1406-1413. [CrossRef] [PubMed]

103. Orini, M.; Taggart, P.; Hayward, M.; Lambiase, P.D. Spatiotemporal characterization of the transition from sinus rhythm to ventricular fibrillation during an acute ischemic event in the intact human heart by whole-heart sock-mapping. Heart Rhythm Case Rep. 2017, 3, 259-263. [CrossRef] [PubMed]

104. Haugaa, K.; Edvardsen, T.; Amlie, J.P. Prediction of Life-Threatening Arrhythmias—Still an Unresolved Problem. Cardiology 2011, 118, 129-137. [CrossRef]

105. León, D.G.; López-Yunta, M.; Alfonso-Almazán, J.M.; Marina-Breysse, M.; Quintanilla, J.G.; Sánchez-González, J.; Galán-Arriola, C.; Castro-Núñez, F.; González-Ferrer, J.J.; Ibáñez, B.; et al. Three-dimensional cardiac fibre disorganization as a novel parameter for ventricular arrhythmia stratification after myocardial infarction. EP Eur. 2019, 21, 822-832. [CrossRef] [PubMed]

106. Pashakhanloo, F.; Herzka, D.A.; Halperin, H.; McVeigh, E.R.; Trayanova, N.A. Role of 3-Dimensional Architecture of Scar and Surviving Tissue in Ventricular Tachycardia. Circ. Arrhythmia Electrophysiol. 2018, 11, e006131. [CrossRef] [PubMed] 
107. Kim, Y.; Chen, S.; Ernst, S.; Guzman, C.E.; Han, S.; Kalarus, Z.; Labadet, C.; Lin, Y.; Lo, L.; Nogami, A.; et al. 2019 APHRS expert consensus statement on three-dimensional mapping systems for tachycardia developed in collaboration with HRS, EHRA, and LAHRS. J. Arrhythmia 2020, 36, 215-270. [CrossRef] [PubMed]

108. Gepstein, L.; Hayam, G.; Ben-Haim, S.A. A novel method for nonfluoroscopic catheter-based electroanatomical mapping of the heart. In vitro and in vivo accuracy results. Circulation 1997, 95, 1611-1622. [CrossRef]

109. Wolf, M.; Sacher, F.; Cochet, H.; Kitamura, T.; Takigawa, M.; Yamashita, S.; Vlachos, K.; Cheniti, G.; Frontera, A.; Martin, R.; et al. Long-Term Outcome of Substrate Modification in Ablation of Post-Myocardial Infarction Ventricular Tachycardia. Circ. Arrhythmia Electrophysiol. 2018, 11, e005635. [CrossRef]

110. Briceño, D.F.; Romero, J.; Villablanca, P.A.; Londoño, A.; Diaz, J.C.; Maraj, I.; Batul, S.A.; Madan, N.; Patel, J.; Jagannath, A.; et al. Long-term outcomes of different ablation strategies for ventricular tachycardia in patients with structural heart disease: Systematic review and meta-analysis. EP Eur. 2017, 20, 104-115. [CrossRef]

111. Bogun, F.; Crawford, T.; Chalfoun, N.; Kühne, M.; Sarrazin, J.-F.; Wells, D.; Good, E.; Jongnarangsin, K.; Oral, H.; Chugh, A.; et al. Relationship of frequent postinfarction premature ventricular complexes to the reentry circuit of scarrelated ventricular tachycardia. Heart Rhythm. 2008, 5, 367-374. [CrossRef] [PubMed]

112. Marrouche, N.F.; Verma, A.; Wazni, O.; Schweikert, R.; Martin, D.O.; Saliba, W.; Kilicaslan, F.; Cummings, J.; Burkhardt, J.; Bhargava, M.; et al. Mode of initiation and ablation of ventricular fibrillation storms in patients with ischemic cardiomyopathy. $J$. Am. Coll. Cardiol. 2004, 43, 1715-1720. [CrossRef] [PubMed]

113. Okada, D.R.; Miller, J.; Chrispin, J.; Prakosa, A.; Trayanova, N.; Jones, S.; Maggioni, M.; Wu, K.C. Substrate Spatial Complexity Analysis for the Prediction of Ventricular Arrhythmias in Patients with Ischemic Cardiomyopathy. Circ. Arrhythmia Electrophysiol. 2020, 13, e007975. [CrossRef] [PubMed]

114. Prakosa, A.; Arevalo, H.J.; Deng, D.; Boyle, P.M.; Nikolov, P.P.; Ashikaga, H.; Blauer, J.J.E.; Ghafoori, E.; Park, C.J.; Blake, R.C.; et al. Personalized virtual-heart technology for guiding the ablation of infarct-related ventricular tachycardia. Nat. Biomed. Eng. 2018, 2, 732-740. [CrossRef]

115. Sharma, A.; Wong, D.; Weidlich, G.; Fogarty, T.; Jack, A.; Sumanaweera, T.; Maguire, P. Noninvasive stereotactic radiosurgery (CyberHeart) for creation of ablation lesions in the atrium. Heart Rhythm. 2010, 7, 802-810. [CrossRef] [PubMed]

116. Lindsey, M.L.; Bolli, R.; Canty, J.M.; Du, X.-J.; Frangogiannis, N.; Frantz, S.; Gourdie, R.G.; Holmes, J.; Jones, S.P.; Kloner, R.A.; et al. Guidelines for experimental models of myocardial ischemia and infarction. Am. J. Physiol. Circ. Physiol. 2018, 314, H812-H838. [CrossRef]

117. Anversa, P.; Beghi, C.; Kikkawa, Y.; Olivetti, G. Myocardial response to infarction in the rat. Morphometric measurement of infarct size and myocyte cellular hypertrophy. Am. J. Pathol. 1985, 118, 484-492. [PubMed]

118. Anversa, P.; Olivetti, G.; Capasso, J.M. Cellular basis of ventricular remodeling after myocardial infarction. Am. J. Cardiol. 1991, 68, 7-16. [CrossRef]

119. Heusch, G.; Skyschally, A.; Schulz, R. The in-situ pig heart with regional ischemia/reperfusion-Ready for translation. J. Mol. Cell. Cardiol. 2011, 50, 951-963. [CrossRef]

120. Canty, J.M., Jr.; Suzuki, G.; Banas, M.D.; Verheyen, F.; Borgers, M.; Fallavollita, J.A. Hibernating Myocardium. Circ. Res. 2004, 94, 1142-1149. [CrossRef]

121. Wu, M.; D’Hooge, J.; Ganame, J.; Ferferieva, V.; Sipido, K.R.; Maes, F.; Dymarkowski, S.; Bogaert, J.; Rademakers, F.E.; Claus, P. Non-invasive characterization of the area-at-risk using magnetic resonance imaging in chronic ischaemia. Cardiovasc. Res. 2011, 89, 166-174. [CrossRef] [PubMed]

122. Wolf, E.; Kemter, E.; Klymiuk, N.; Reichart, B. Genetically modified pigs as donors of cells, tissues, and organs for xenotransplantation. Anim. Front. 2019, 9, 13-20. [CrossRef] [PubMed]

123. Längin, M.; Mayr, T.; Reichart, B.; Michel, S.; Buchholz, S.; Guethoff, S.; Dashkevich, A.; Baehr, A.; Egerer, S.; Bauer, A.; et al. Consistent success in life-supporting porcine cardiac xenotransplantation. Nature 2018, 564, 430-433. [CrossRef] [PubMed]

124. DeSantiago, J.; Ai, X.; Islam, M.; Acuna, G.; Ziolo, M.T.; Bers, D.; Pogwizd, S.M. Arrhythmogenic Effects of $\beta 2$-Adrenergic Stimulation in the Failing Heart Are Attributable to Enhanced Sarcoplasmic Reticulum Ca Load. Circ. Res. 2008, 102, 1389-1397. [CrossRef]

125. Currie, S.; Quinn, F.R.; Sayeed, R.; Duncan, A.M.; Kettlewell, S.; Smith, G.L. Selective down-regulation of sub-endocardial ryanodine receptor expression in a rabbit model of left ventricular dysfunction. J. Mol. Cell. Cardiol. 2005, 39, 309-317. [CrossRef]

126. De Villiers, C.; Riley, P.R. Mouse models of myocardial infarction: Comparing permanent ligation and ischaemia-reperfusion. Dis. Model. Mech. 2020, 13, 046565. [CrossRef]

127. Dewald, O.; Ren, G.; Duerr, G.D.; Zoerlein, M.; Klemm, C.; Gersch, C.; Tincey, S.; Michael, L.H.; Entman, M.L.; Frangogiannis, N. Of Mice and Dogs: Species-Specific Differences in the Inflammatory Response Following Myocardial Infarction. Am. J. Pathol. 2004, 164, 665-677. [CrossRef]

128. Fu, X.; Khalil, H.; Kanisicak, O.; Boyer, J.G.; Vagnozzi, R.J.; Maliken, B.D.; Sargent, M.A.; Prasad, V.; Valiente-Alandi, I.; Blaxall, B.C.; et al. Specialized fibroblast differentiated states underlie scar formation in the infarcted mouse heart. J. Clin. Investig. 2018, 128, 2127-2143. [CrossRef]

129. Humeres, C.; Frangogiannis, N.G. Fibroblasts in the Infarcted, Remodeling, and Failing Heart. JACC Basic Transl. Sci. 2019, 4, 449-467. [CrossRef] [PubMed] 
130. Houser, S.R.; Margulies, K.B.; Murphy, A.M.; Spinale, F.G.; Francis, G.S.; Prabhu, S.D.; Rockman, H.A.; Kass, D.A.; Molkentin, J.; Sussman, M.A.; et al. Animal Models of Heart Failure. Circ. Res. 2012, 111, 131-150. [CrossRef] [PubMed]

131. Sala, L.; Hegyi, B.; Bartolucci, C.; Altomare, C.; Rocchetti, M.; Váczi, K.; Mostacciuolo, G.; Szentandrássy, N.; Severi, S.; Nánási, P.P.; et al. Action potential contour contributes to species differences in repolarization response to $\beta$-adrenergic stimulation. EP Eur. 2018, 20, 1543-1552. [CrossRef] [PubMed]

132. de Boer, T.; Stengl, M. Action potential contour and inter-species differences. EP Eur. 2017, 20, 1395-1396. [CrossRef] [PubMed]

133. O'Hara, T.; Rudy, Y. Quantitative comparison of cardiac ventricular myocyte electrophysiology and response to drugs in human and nonhuman species. Am. J. Physiol. Circ. Physiol. 2012, 302, H1023-H1030. [CrossRef] [PubMed]

134. Pinto, J.M.B. Electrical remodeling in ischemia and infarction. Cardiovasc. Res. 1999, 42, 284-297. [CrossRef]

135. Nattel, S. Electrical coupling between cardiomyocytes and fibroblasts: Experimental testing of a challenging and important concept. Cardiovasc. Res. 2018, 114, 349-352. [CrossRef] [PubMed]

136. Tomaselli, G.F. Electrophysiological remodeling in hypertrophy and heart failure. Cardiovasc. Res. 1999, 42, 270-283. [CrossRef]

137. Litwin, S.E.; Bridge, J.H. Enhanced $\mathrm{Na}(+)-\mathrm{Ca} 2+$ exchange in the infarcted heart. Implications for excitation-contraction coupling. Circ. Res. 1997, 81, 1083-1093. [CrossRef]

138. Wit, A.L.; Peters, N.S. The role of gap junctions in the arrhythmias of ischemia and infarction. Heart Rhythm. 2012, 9, 308-311. [CrossRef]

139. Wong, S.S.; Bassett, A.L.; Cameron, J.S.; Epstein, K.; Kozlovskis, P.; Myerburg, R.J. Dissimilarities in the electrophysiological abnormalities of lateral border and central infarct zone cells after healing of myocardial infarction in cats. Circ. Res. 1982, 51, 486-493. [CrossRef]

140. Boyden, P.A.; Albala, A.; Dresdner, K.P., Jr. Electrophysiology and ultrastructure of canine subendocardial Purkinje cells isolated from control and 24-hour infarcted hearts. Circ. Res. 1989, 65, 955-970. [CrossRef]

141. Ursell, P.C.; Gardner, P.I.; Albala, A.; Fenoglio, J.J., Jr.; Wit, A.L. Structural and electrophysiological changes in the epicardial border zone of canine myocardial infarcts during infarct healing. Circ. Res. 1985, 56, 436-451. [CrossRef]

142. Haissaguerre, M.; Vigmond, E.; Stuyvers, B.; Hocini, M.; Bernus, O. Ventricular arrhythmias and the His-Purkinje system. Nat. Rev. Cardiol. 2016, 13, 155-166. [CrossRef]

143. Cabo, C.; Boyden, P.A. Electrical remodeling of the epicardial border zone in the canine infarcted heart: A computational analysis. Am. J. Physiol. Circ. Physiol. 2003, 284, H372-H384. [CrossRef]

144. Myerburg, R.J.; Epstein, K.; Gaide, M.S.; Wong, S.S.; Castellanos, A.; Gelband, H.; Bassett, A.L. Electrophysiologic consequences of experimental acute ischemia superimposed on healed myocardial infarction in cats. Am. J. Cardiol. 1982, 49, 323-330. [CrossRef]

145. Huang, B.; Qin, D.; El-Sherif, N. Spatial alterations of Kv channels expression and K(+) currents in post-MI remodeled rat heart. Cardiovasc. Res. 2001, 52, 246-254. [CrossRef]

146. Schwartz, P.J.; Vanoli, E.; Stramba-Badiale, M.; De Ferrari, G.M.; Billman, G.E.; Foreman, R.D. Autonomic mechanisms and sudden death. New insights from analysis of baroreceptor reflexes in conscious dogs with and without a myocardial infarction. Circulation 1988, 78, 969-979. [CrossRef]

147. Myles, R.C.; Burton, F.L.; Cobbe, S.M.; Smith, G.L. Alternans of action potential duration and amplitude in rabbits with left ventricular dysfunction following myocardial infarction. J. Mol. Cell. Cardiol. 2011, 50, 510-521. [CrossRef]

148. Tsujii, E.; Tanaka, H.; Oyamada, M.; Fujita, K.; Hamamoto, T.; Takamatsu, T. In situ visualization of the intracellular Ca2+ dynamics at the border of the acute myocardial infarct. Mol. Cell. Biochem. 2003, 248, 135-139. [CrossRef] [PubMed]

149. Takahashi, T.; van Dessel, P.; Lopshire, J.C.; Groh, W.J.; Miller, J.; Wu, J.; Zipes, D. Optical mapping of the functional reentrant circuit of ventricular tachycardia in acute myocardial infarction. Heart Rhythm. 2004, 1, 451-459. [CrossRef] [PubMed]

150. Cabo, C.; Yao, J.; Boyden, P.A.; Chen, S.; Hussain, W.; Duffy, H.S.; Ciaccio, E.J.; Peters, N.S.; Wit, A.L. Heterogeneous gap junction remodeling in reentrant circuits in the epicardial border zone of the healing canine infarct. Cardiovasc. Res. 2006, 72, 241-249. [CrossRef] [PubMed]

151. Hund, T.J.; Decker, K.F.; Kanter, E.; Mohler, P.J.; Boyden, P.A.; Schuessler, R.B.; Yamada, K.A.; Rudy, Y. Role of activated CaMKII in abnormal calcium homeostasis and INa remodeling after myocardial infarction: Insights from mathematical modeling. J. Mol. Cell. Cardiol. 2008, 45, 420-428. [CrossRef] [PubMed]

152. Chou, C.-C.; Zhou, S.; Hayashi, H.; Nihei, M.; Liu, Y.-B.; Wen, M.-S.; Yeh, S.-J.; Fishbein, M.C.; Weiss, J.N.; Lin, S.-F.; et al. Remodelling of action potential and intracellular calcium cycling dynamics during subacute myocardial infarction promotes ventricular arrhythmias in Langendorff-perfused rabbit hearts. J. Physiol. 2007, 580, 895-906. [CrossRef] [PubMed]

153. Mills, W.R.; Mal, N.; Forudi, F.; Popović, Z.B.; Penn, M.S.; Laurita, K.R. Optical mapping of late myocardial infarction in rats. Am. J. Physiol. Circ. Physiol. 2006, 290, H1298-H1306. [CrossRef] [PubMed]

154. Pop, M.; Sermesant, M.; Liu, G.; Relan, J.; Mansi, T.; Soong, A.; Peyrat, J.-M.; Truong, M.V.; Fefer, P.; McVeigh, E.R.; et al. Construction of 3D MR image-based computer models of pathologic hearts, augmented with histology and optical fluorescence imaging to characterize action potential propagation. Med. Image Anal. 2012, 16, 505-523. [CrossRef]

155. Pinali, C.; Malik, N.; Davenport, J.B.; Allan, L.J.; Murfitt, L.; Iqbal, M.M.; Boyett, M.R.; Wright, E.J.; Walker, R.; Zhang, Y.; et al. Post-Myocardial Infarction T-tubules Form Enlarged Branched Structures with Dysregulation of Junctophilin-2 and Bridging Integrator 1 (BIN-1). J. Am. Heart Assoc. 2017, 6, e004834. [CrossRef]

156. Dun, W.; Baba, S.; Yagi, T.; Boyden, P.A. Dynamic remodeling of K+ and Ca2+ currents in cells that survived in the epicardial border zone of canine healed infarcted heart. Am. J. Physiol. Circ. Physiol. 2004, 287, H1046-H1054. [CrossRef] 
157. Kim, Y.-K.; Kim, S.-J.; Kramer, C.M.; Yatani, A.; Takagi, G.; Mankad, S.; Szigeti, G.P.; Singh, D.; Bishop, S.P.; Shannon, R.P.; et al. Altered Excitation-Contraction Coupling in Myocytes from Remodeled Myocardium after Chronic Myocardial Infarction. J. Mol. Cell. Cardiol. 2002, 34, 63-73. [CrossRef]

158. Shimkunas, R.; Zhang, Z.; Wenk, J.F.; Soleimani, M.; Khazalpour, M.; Acevedo-Bolton, G.; Wang, G.; Saloner, D.; Mishra, R.; Wallace, A.W.; et al. Left Ventricular Myocardial Contractility Is Depressed in the Borderzone after Posterolateral Myocardial Infarction. Ann. Thorac. Surg. 2013, 95, 1619-1625. [CrossRef]

159. Kimura, S.; Bassett, A.L.; Kohya, T.; Kozlovskis, P.L.; Myerburg, R.J. Simultaneous recording of action potentials from endocardium and epicardium during ischemia in the isolated cat ventricle: Relation of temporal electrophysiologic heterogeneities to arrhythmias. Circulation 1986, 74, 401-409. [CrossRef]

160. Pinto, J.M.; Yuan, F.; Wasserlaue, B.J.; Bassett, A.L.; Myerburg, R.J. Regional Gradation of L-Type Calcium Currents in the Feline Heart with a Healed Myocardial Infarct. J. Cardiovasc. Electrophysiol. 1997, 8, 548-560. [CrossRef]

161. Kimura, S.; Bassett, A.L.; Cameron, J.S.; Huikuri, H.; Kozlovskis, P.L.; Myerburg, R.J. Cellular electrophysiological changes during ischemia in isolated, coronary-perfused cat ventricle with healed myocardial infarction. Circulation 1988, 78, 401-406. [CrossRef]

162. Weigand, K.; Witte, R.; Moukabary, T.; Chinyere, I.; Lancaster, J.; Pierce, M.K.; Goldman, S.; Juneman, E. In vivo Electrophysiological Study of Induced Ventricular Tachycardia in Intact Rat Model of Chronic Ischemic Heart Failure. IEEE Trans. Biomed. Eng. 2016, 64, 1393-1399. [CrossRef]

163. Walker, N.L.; Burton, F.L.; Kettlewell, S.; Smith, G.L.; Cobbe, S.M. Mapping of Epicardial Activation in a Rabbit Model of Chronic Myocardial Infarction. J. Cardiovasc. Electrophysiol. 2007, 18, 862-868. [CrossRef] [PubMed]

164. Dangman, K.H.; Danilo, P., Jr.; Hordof, A.J.; Mary-Rabine, L.; Reder, R.F.; Rosen, M.R. Electrophysiologic characteristics of human ventricular and Purkinje fibers. Circulation 1982, 65, 362-368. [CrossRef] [PubMed]

165. Loennechen, J.P.; Wisløff, U.; Falck, G.; Ellingsen, Ø. Cardiomyocyte contractility and calcium handling partially recover after early deterioration during post-infarction failure in rat. Acta Physiol. Scand. 2002, 176, 17-26. [CrossRef]

166. Kilic, A.; Li, T.; Nolan, T.D.C.; Nash, J.R.; Li, S.; Prastein, D.J.; Schwartzbauer, G.; Moainie, S.L.; Yankey, G.K.; Defilippi, C.; et al. Strain-related regional alterations of calcium-handling proteins in myocardial remodeling. J. Thorac. Cardiovasc. Surg. 2006, 132, 900-908. [CrossRef] [PubMed]

167. Tomek, J.; Hao, G.; Tomkova, M.; Lewis, A.; Carr, C.; Paterson, D.J.; Rodriguez, B.; Bub, G.; Herring, N. $\beta$-Adrenergic Receptor Stimulation and Alternans in the Border Zone of a Healed Infarct: An ex vivo Study and Computational Investigation of Arrhythmogenesis. Front. Physiol. 2019, 10, 350. [CrossRef]

168. Belevych, A.; Terentyev, D.; Terentyeva, R.; Nishijima, Y.; Sridhar, A.; Hamlin, R.L.; Carnes, C.; Györke, S. The relationship between arrhythmogenesis and impaired contractility in heart failure: Role of altered ryanodine receptor function. Cardiovasc. Res. 2011, 90, 493-502. [CrossRef]

169. Belevych, A.E.; Terentyev, D.; Terentyeva, R.; Ho, H.-T.; Gyorke, I.; Bonilla, I.M.; Carnes, C.A.; Billman, G.E.; Györke, S. Shortened $\mathrm{Ca} 2+$ signaling refractoriness underlies cellular arrhythmogenesis in a postinfarction model of sudden cardiac death. Circ. Res. 2012, 110, 569-577. [CrossRef]

170. Hirose, M.; Stuyvers, B.D.; Dun, W.; ter Keurs, H.E.; Boyden, P.A. Function of Ca 2+ Release Channels in Purkinje Cells That Survive in the Infarcted Canine Heart. Circ. Arrhythmia Electrophysiol. 2008, 1, 387-395. [CrossRef]

171. Boyden, P.A.; Barbhaiya, C.; Lee, T.; Ter Keurs, H.E. Nonuniform Ca2+ transients in arrhythmogenic Purkinje cells that survive in the infarcted canine heart. Cardiovasc. Res. 2003, 57, 681-693. [CrossRef]

172. Ter Keurs, H.E.D.J.; Boyden, P.A. Calcium and Arrhythmogenesis. Physiol. Rev. 2007, 87, 457-506. [CrossRef]

173. Jalife, J. Modulated parasystole: Still relevant after all these years! Heart Rhythm. 2013, 10, 1441-1443. [CrossRef]

174. Tallquist, M.D.; Molkentin, J.D. Redefining the identity of cardiac fibroblasts. Nat. Rev. Cardiol. 2017, 14, 484-491. [CrossRef]

175. Ruiz-Villalba, A.; Romero, J.P.; Hernandez, S.C.; Vilas-Zornoza, A.; Fortelny, N.; Castro-Labrador, L.; Martin-Uriz, P.S.; LorenzoVivas, E.; García-Olloqui, P.; Palacios, M.; et al. Single-Cell RNA-seq Analysis Reveals a Crucial Role for Collagen Triple Helix Repeat Containing 1 (CTHRC1) Cardiac Fibroblasts after Myocardial Infarction. Circulation 2020, 142, 1831-1847. [CrossRef]

176. Nagaraju, C.K.; Dries, E.; Gilbert, G.; Abdesselem, M.; Wang, N.; Amoni, M.; Driesen, R.B.; Sipido, K.R. Myofibroblast modulation of cardiac myocyte structure and function. Sci. Rep. 2019, 9, 1-11. [CrossRef]

177. Quinn, T.A.; Camelliti, P.; Rog-Zielinska, E.A.; Siedlecka, U.; Poggioli, T.; O’Toole, E.T.; Knopfel, T.; Kohl, P. Electrotonic coupling of excitable and nonexcitable cells in the heart revealed by optogenetics. Proc. Natl. Acad. Sci. USA 2016, 113, 14852-14857. [CrossRef] [PubMed]

178. Schultz, F.; Swiatlowska, P.; Alvarez-Laviada, A.; Sanchez-Alonso, J.L.; Song, Q.; de Vries, A.A.F.; Pijnappels, D.A.; Ongstad, E.; Braga, V.M.M.; Entcheva, E.; et al. Cardiomyocyte-myofibroblast contact dynamism is modulated by connexin-43. FASEB J. 2019, 33, 10453-10468. [CrossRef] [PubMed]

179. Rubart, M.; Tao, W.; Lu, X.-L.; Conway, S.J.; Reuter, S.P.; Lin, S.-F.; Soonpaa, M.H. Electrical coupling between ventricular myocytes and myofibroblasts in the infarcted mouse heart. Cardiovasc. Res. 2018, 114, 389-400. [CrossRef] [PubMed]

180. Kim, G.H. MicroRNA regulation of cardiac conduction and arrhythmias. Transl. Res. 2013, 161, 381-392. [CrossRef] [PubMed]

181. Bang, C.; Batkai, S.; Dangwal, S.; Gupta, S.K.; Foinquinos, A.; Holzmann, A.; Just, A.; Remke, J.; Zimmer, K.; Zeug, A.; et al. Cardiac fibroblast-derived microRNA passenger strand-enriched exosomes mediate cardiomyocyte hypertrophy. J. Clin. Investig. 2014, 124, 2136-2146. [CrossRef] [PubMed] 
182. Shen, M.J.; Zipes, D.P. Role of the Autonomic Nervous System in Modulating Cardiac Arrhythmias. Circ. Res. 2014, 114, 1004-1021. [CrossRef] [PubMed]

183. Vaseghi, M.; Shivkumar, K. The Role of the Autonomic Nervous System in Sudden Cardiac Death. Prog. Cardiovasc. Dis. 2008, 50, 404-419. [CrossRef] [PubMed]

184. Gardner, R.T.; Ripplinger, C.; Myles, R.; Habecker, B.A. Molecular Mechanisms of Sympathetic Remodeling and Arrhythmias. Circ. Arrhythmia Electrophysiol. 2016, 9, e001359. [CrossRef]

185. Vanoli, E.; De Ferrari, G.M.; Stramba-Badiale, M.; Hull, S.S., Jr.; Foreman, R.D.; Schwartz, P.J. Vagal stimulation and prevention of sudden death in conscious dogs with a healed myocardial infarction. Circ. Res. 1991, 68, 1471-1481. [CrossRef]

186. Wang, L.; Olivas, A.; Stuart, S.D.F.; Tapa, S.; Blake, M.R.; Woodward, W.R.; Habecker, B.A.; Ripplinger, C.M. Cardiac sympathetic nerve transdifferentiation reduces action potential heterogeneity after myocardial infarction. Am. J. Physiol. Circ. Physiol. 2020, 318, H558-H565. [CrossRef]

187. Jiang, H.; Lu, Z.; Yu, Y.; Zhao, D.; Yang, B.; Huang, C. Relationship between sympathetic nerve sprouting and repolarization dispersion at peri-infarct zone after myocardial infarction. Auton. Neurosci. 2007, 134, 18-25. [CrossRef]

188. Yoshioka, K.; Gao, D.-W.; Chin, M.; Stillson, C.; Penades, E.; Lesh, M.; O'Connell, W.; Dae, M. Heterogeneous Sympathetic Innervation Influences Local Myocardial Repolarization in Normally Perfused Rabbit Hearts. Circulation 2000, 101, 1060-1066. [CrossRef]

189. Vaseghi, M.; Lux, R.L.; Mahajan, A.; Shivkumar, K. Sympathetic stimulation increases dispersion of repolarization in humans with myocardial infarction. Am. J. Physiol. Circ. Physiol. 2012, 302, H1838-H1846. [CrossRef]

190. Priori, S.G.; Mantica, M.; Schwartz, P.J. Delayed afterdepolarizations elicited in vivo by left stellate ganglion stimulation. Circulation 1988, 78, 178-185. [CrossRef] [PubMed]

191. Xie, Y.; Sato, D.; Garfinkel, A.; Qu, Z.; Weiss, J.N. So Little Source, So Much Sink: Requirements for Afterdepolarizations to Propagate in Tissue. Biophys. J. 2010, 99, 1408-1415. [CrossRef]

192. Dries, E.; Santiago, D.J.; Gilbert, G.; Lenaerts, I.; Vandenberk, B.; Nagaraju, C.K.; Johnson, D.M.; Holemans, P.; Roderick, H.; Macquaide, N.; et al. Hyperactive ryanodine receptors in human heart failure and ischaemic cardiomyopathy reside outside of couplons. Cardiovasc. Res. 2018, 114, 1512-1524. [CrossRef] [PubMed]

193. Schobesberger, S.; Wright, P.; Tokar, S.; Bhargava, A.; Mansfield, C.; Glukhov, A.V.; Poulet, C.; Buzuk, A.; Monszpart, A.; Sikkel, M.; et al. T-tubule remodelling disturbs localized $\beta 2$-adrenergic signalling in rat ventricular myocytes during the progression of heart failure. Cardiovasc. Res. 2017, 113, 770-782. [CrossRef] [PubMed]

194. Vaseghi, M.; Gima, J.; Kanaan, C.; Ajijola, O.; Marmureanu, A.; Mahajan, A.; Shivkumar, K. Cardiac sympathetic denervation in patients with refractory ventricular arrhythmias or electrical storm: Intermediate and long-term follow-up. Heart Rhythm. 2014, 11,360-366. [CrossRef] [PubMed]

195. Marx, S.O.; Reiken, S.; Hisamatsu, Y.; Jayaraman, T.; Burkhoff, D.; Rosemblit, N.; Marks, A.R. PKA Phosphorylation Dissociates FKBP12.6 from the Calcium Release Channel (Ryanodine Receptor): Defective Regulation in Failing Hearts. Cell 2000, 101, 365-376. [CrossRef]

196. Wehrens, X.; Lehnart, S.E.; Marks, A.R. Ryanodine Receptor-Targeted Anti-Arrhythmic Therapy. Ann. N. Y. Acad. Sci. 2005, 1047, 366-375. [CrossRef]

197. Antoons, G.; Willems, R.; Sipido, K.R. Alternative strategies in arrhythmia therapy: Evaluation of Na/Ca exchange as an anti-arrhythmic target. Pharmacol. Ther. 2011, 134, 26-42. [CrossRef]

198. Liu, N.; Napolitano, C.; Venetucci, L.A.; Priori, S.G. Flecainide and Antiarrhythmic Effects in a Mouse Model of Catecholaminergic Polymorphic Ventricular Tachycardia. Trends Cardiovasc. Med. 2012, 22, 35-39. [CrossRef]

199. Kryshtal, D.O.; Blackwell, D.J.; Egly, C.L.; Smith, A.N.; Batiste, S.M.; Johnston, J.N.; Laver, D.R.; Knollmann, B.C. RYR2 Channel Inhibition Is the Principal Mechanism of Flecainide Action in CPVT. Circ. Res. 2021, 128, 321-331. [CrossRef]

200. Zhou, Q.; Xiao, J.; Jiang, D.; Wang, R.; Vembaiyan, K.; Wang, A.; Smith, C.D.; Xie, C.; Chen, W.; Zhang, J.; et al. Carvedilol and its new analogs suppress arrhythmogenic store overload-induced Ca2+ release. Nat. Med. 2011, 17, 1003-1009. [CrossRef]

201. Maruyama, M.; Xiao, J.; Zhou, Q.; Vembaiyan, K.; Chua, S.-K.; Der Lohe, M.R.-V.; Lin, S.-F.; Back, T.G.; Chen, S.R.W.; Chen, P.-S Carvedilol analogue inhibits triggered activities evoked by both early and delayed afterdepolarizations. Heart Rhythm. 2012, 10, 101-107. [CrossRef] [PubMed]

202. Li, N.; Wang, Q.; Sibrian-Vazquez, M.; Klipp, R.C.; Reynolds, J.O.; Word, T.A.; Scott, L.; Salama, G.; Strongin, R.M.; Abramson, J.J.; et al. Treatment of catecholaminergic polymorphic ventricular tachycardia in mice using novel RyR2-modifying drugs. Int. J. Cardiol. 2017, 227, 668-673. [CrossRef] [PubMed]

203. Pabel, S.; Mustroph, J.; Stehle, T.; Lebek, S.; Dybkova, N.; Keyser, A.; Rupprecht, L.; Wagner, S.; Neef, S.; Maier, L.S.; et al. Dantrolene reduces CaMKII C-mediated atrial arrhythmias. EP Eur. 2020, 22, 1111-1118. [CrossRef]

204. Antoons, G.; Johnson, D.M.; Dries, E.; Santiago, D.J.; Ozdemir, S.; Lenaerts, I.; Beekman, J.D.; Houtman, M.J.; Sipido, K.R.; Vos, M.A. Calcium release near l-type calcium channels promotes beat-to-beat variability in ventricular myocytes from the chronic AV block dog. J. Mol. Cell. Cardiol. 2015, 89, 326-334. [CrossRef]

205. Johnson, D.M.; Heijman, J.; Pollard, C.E.; Valentin, J.-P.; Crijns, H.J.; Abi-Gerges, N.; Volders, P.G. IKs restricts excessive beat-to-beat variability of repolarization during beta-adrenergic receptor stimulation. J. Mol. Cell. Cardiol. 2010, 48, 122-130. [CrossRef] 
206. Heijman, J.; Zaza, A.; Johnson, D.M.; Rudy, Y.; Peeters, R.; Volders, P.G.A.; Westra, R.L. Determinants of Beat-to-Beat Variability of Repolarization Duration in the Canine Ventricular Myocyte: A Computational Analysis. PLoS Comput. Biol. 2013,9 , e1003202. [CrossRef]

207. Donahue, J.K. Gene Therapy for Post-Infarction Ventricular Tachycardia; Springer: New York, NY, USA, 2017; Volume 1521, pp. 307-321.

208. Young, A.A.; Crossman, D.J.; Ruygrok, P.N.; Cannell, M.B. Mapping system for coregistration of cardiac mri and ex vivo tissue sampling. J. Magn. Reson. Imaging 2011, 34, 1065-1071. [CrossRef]

209. Dauwe, D.; Nuyens, D.; De Buck, S.; Claus, P.; Gheysens, O.; Koole, M.; Coudyzer, W.; Driessche, N.V.; Janssens, L.; Ector, J.; et al. Three-dimensional rotational angiography fused with multimodal imaging modalities for targeted endomyocardial injections in the ischaemic heart. Eur. Heart J. Cardiovasc. Imaging 2014, 15, 900-907. [CrossRef]

210. Sasano, T.; McDonald, A.D.; Kikuchi, K.; Donahue, J.K. Molecular ablation of ventricular tachycardia after myocardial infarction. Nat. Med. 2006, 12, 1256-1258. [CrossRef]

211. Hesse, M.; Bednarz, R.; Carls, E.; Becker, C.; Bondareva, O.; Lother, A.; Geisen, C.; Dreßen, M.; Krane, M.; Roell, W.; et al. Proximity to injury, but neither number of nuclei nor ploidy define pathological adaptation and plasticity in cardiomyocytes. $J$. Mol. Cell. Cardiol. 2021, 152, 95-104. [CrossRef]

212. Kuppe, C.; Flores, R.O.; Li, Z.; Hannani, M.; Tanevski, J.; Halder, M.; Cheng, M.; Ziegler, S.; Zhang, X.; Preisker, F.; et al. Spatial multi-omic map of human myocardial infarction. Bioxiv 2020. [CrossRef]

213. Preissl, S.; Schwaderer, M.; Raulf, A.; Hesse, M.; Grüning, B.; Köbele, C.; Backofen, R.; Fleischmann, B.K.; Hein, L.; Gilsbach, R. Deciphering the Epigenetic Code of Cardiac Myocyte Transcription. Circ. Res. 2015, 117, 413-423. [CrossRef]

214. Thienpont, B.; Aronsen, J.M.; Robinson, E.L.; Okkenhaug, H.; Loche, E.; Ferrini, A.; Brien, P.; Alkass, K.; Tomasso, A.; Agrawal, A.; et al. The H3K9 dimethyltransferases EHMT1/2 protect against pathological cardiac hypertrophy. J. Clin. Investig. 2016, 127, 335-348. [CrossRef]

215. Kolesová, H.; Olejníčková, V.; Kvasilová, A.; Gregorovičová, M.; Sedmera, D. Tissue clearing and imaging methods for cardiovascular development. iScience 2021, 24, 102387. [CrossRef] [PubMed]

216. Fischesser, D.M.; Meyer, E.C.; Sargent, M.; Molkentin, J.D. Refined CLARITY-Based Tissue Clearing for Three-Dimensional Fibroblast Organization in Healthy and Injured Mouse Hearts. J. Vis. Exp. 2021, 171, e62023. [CrossRef]

217. Litviňuková, M.; Talavera-López, C.; Maatz, H.; Reichart, D.; Worth, C.L.; Lindberg, E.L.; Kanda, M.; Polanski, K.; Heinig, M.; Lee, M.; et al. Cells of the adult human heart. Nature 2020, 588, 466-472. [CrossRef] [PubMed]

218. Tucker, N.R.; Chaffin, M.; Fleming, S.; Hall, A.; Parsons, V.A.; Bedi, K.C.; Akkad, A.-D.; Herndon, C.N.; Arduini, A.; Papangeli, I.; et al. Transcriptional and Cellular Diversity of the Human Heart. Circulation 2020, 142, 466-482. [CrossRef]

219. Browaeys, R.; Saelens, W.; Saeys, Y. NicheNet: Modeling intercellular communication by linking ligands to target genes. Nat. Methods 2020, 17, 159-162. [CrossRef]

220. Kelsey, G.; Stegle, O.; Reik, W. Single-cell epigenomics: Recording the past and predicting the future. Science 2017, 358, 69-75. [CrossRef] [PubMed]

221. Watson, S.; Scigliano, M.; Bardi, I.; Ascione, R.; Terracciano, C.M.; Perbellini, F. Preparation of viable adult ventricular myocardial slices from large and small mammals. Nat. Protoc. 2017, 12, 2623-2639. [CrossRef]

222. Schneider-Warme, F.; Johnston, C.M.; Kohl, P. Organotypic myocardial slices as model system to study heterocellular interactions. Cardiovasc. Res. 2017, 114, 3-6. [CrossRef] [PubMed]

223. Hulsmans, M.; Clauss, S.; Xiao, L.; Aguirre, A.D.; King, K.R.; Hanley, A.; Hucker, W.J.; Wülfers, E.M.; Seemann, G.; Courties, G.; et al. Macrophages Facilitate Electrical Conduction in the Heart. Cell 2017, 169, 510-522. [CrossRef] [PubMed]

224. Simon-Chica, A.; Fernández, M.C.; Wülfers, E.M.; Lother, A.; Hilgendorf, I.; Seemann, G.; Ravens, U.; Kohl, P.; Schneider-Warme, F. Novel insights into the electrophysiology of murine cardiac macrophages: Relevance of voltage-gated potassium channels. Cardiovasc. Res. 2021. [CrossRef] 